\title{
Validation of 10-year SAO OMI Ozone Profile (PROFOZ) product using ozonesonde observations
}

Guanyu Huang ${ }^{1}$, Xiong Liu ${ }^{1}$, Kelly Chance ${ }^{1}$, Kai Yang ${ }^{2}$, Pawan K. Bhartia ${ }^{3}$, Zhaonan Cai ${ }^{1}$, Marc Allaart ${ }^{4}$, Gérard Ancellet $^{5}$, Bertrand Calpini ${ }^{6}$, Gerrie J. R. Coetzee $^{7}$, Emilio Cuevas-Agulló ${ }^{8}$, Manuel Cupeiro ${ }^{9}$, Hugo De Backer ${ }^{10}$, Manvendra K. Dubey ${ }^{11}$, Henry E. Fuelberg ${ }^{12}$, Masatomo Fujiwara ${ }^{13}$, Sophie Godin-Beekmann ${ }^{5}$, Tristan J. Hall ${ }^{12}$, Bryan Johnson ${ }^{14}$, Everette Joseph ${ }^{15}$, Rigel Kivi ${ }^{16}$, Bogumil Kois ${ }^{17}$, Ninong Komala ${ }^{18}$, Gert König-Langlo $^{19}$, Giovanni Laneve ${ }^{20}$, Thierry Leblanc ${ }^{21}$, Marion Marchand ${ }^{5}$, Kenneth R. Minschwaner ${ }^{22}$, Gary Morris $^{23}$, Michael J. Newchurch ${ }^{24}$, Shin-Ya Ogino ${ }^{25}$, Nozomu Ohkawara ${ }^{26}$, Ankie J. M. Piters ${ }^{4}$, Françoise Posny $^{27}$, Richard Querel ${ }^{28}$, Rinus Scheele ${ }^{4}$, Frank J. Schmidlin ${ }^{3}$, Russell C. Schnell ${ }^{14}$, Otto Schrems ${ }^{19}$, Henry Selkirk $^{29}$, Masato Shiotani ${ }^{30}$, Pavla Skrivánková ${ }^{31}$, René Stübi ${ }^{6}$, Ghassan Taha ${ }^{29}$, David W. Tarasick ${ }^{32}$, Anne M. Thompson ${ }^{3}$, Valérie Thouret ${ }^{33}$, Matthew B. Tully ${ }^{34}$, Roeland Van Malderen ${ }^{10}$, Holger Vömel ${ }^{35}$, Peter von der Gathen ${ }^{36}$, Jacquelyn C. Witte ${ }^{37}$, and Margarita Yela ${ }^{38}$

${ }^{1}$ Harvard-Smithsonian Center for Astrophysics, Cambridge, MA, USA

${ }^{2}$ Department of Atmospheric and Oceanic Science, University of Maryland, College Park, Maryland, USA

${ }^{3}$ NASA Goddard Space Flight Center, Greenbelt, Maryland, USA

${ }^{4}$ Royal Netherlands Meteorological Institute (KNMI), De Bilt, the Netherlands

${ }^{5}$ LATMOS-ISPL, Université Paris 6 Pierre-et-Marie-Curie, Paris, France

${ }^{6}$ MeteoSwiss Aerological Station, Federal Office of Meteorology and Climatology MeteoSwiss, Payerne, Switzerland

${ }^{7}$ South African Weather Service, Pretoria, South Africa

${ }^{8}$ Izana Atmospheric Research Center, Meteorological State Agency of Spain, Santa Cruz de Tenerife, Spain

${ }^{9}$ National Meteorological Service, Ushuaia, Tierra del Fuego, Argentina

${ }^{10}$ Royal Meteorological Institute of Belgium, Brussels, Belgium

${ }^{11}$ Los Alamos National Laboratory, Los Alamos, NM, USA

${ }^{12}$ Earth, Ocean and Atmospheric Sciences, Florida State University, Tallahassee, FL, USA

${ }^{13}$ Faculty of Environmental Earth Science, Hokkaido University, Sapporo, Japan

${ }^{14}$ NOAA/ESRL Global Monitoring Division, Boulder, CO, USA

${ }^{15}$ Atmospheric Sciences Research Center, SUNY at Albany, Albany, NY, USA

${ }^{16}$ Finnish Meteorological Institute, Sodankylä, Finland

${ }^{17}$ The Institute of Meteorology and Water Management, National Research Institute, Warsaw, Poland

${ }^{18}$ Indonesian Institute of Aeronautics and Space (LAPAN), Bandung, Indonesia

${ }^{19}$ Alfred Wegener Institute, Helmholtz Centre for Polar and Marine Research, Bremerhaven, Germany

${ }^{20}$ Earth Observation Satellite Images Applications Lab (EOSIAL), Università di Roma "La Sapienza”, Rome, Italy

${ }^{21}$ Jet Propulsion Laboratory, California Institute of Technology, Wrightwood, CA, USA

${ }^{22}$ Department of Physics, New Mexico Institute of Mining and Technology, Socorro, NM, USA

${ }^{23}$ St. Edward's University, Austin, TX, USA

${ }^{24}$ Department of Atmospheric Science, University of Alabama in Huntsville, Huntsville, AL, USA

${ }^{25}$ Department of Coupled Ocean-Atmosphere-Land Processes Research, Japan Agency for Marine-Earth Science and Technology, Yokosuka, Japan

${ }^{26}$ Global Environment and Marine Department, Japan Meteorological Agency, Tokyo, Japan

${ }^{27}$ Université de la Réunion, Saint Denis, France

${ }^{28}$ National Institute of Water and Atmospheric Research, Lauder, Central Otago, New Zealand

${ }^{29}$ Universities Space Research Association, Greenbelt, MD, USA

${ }^{30}$ Research Institute for Sustainable Humanosphere, Kyoto University, Kyoto, Japan

${ }^{31}$ Upper Air and Surface Observation Department, Czech Hydrometeorological Institute, Prague, Czech Republic 
${ }^{32}$ Air Quality Research Division, Environment \& Climate Change Canada, Downsview, ON, Canada

${ }^{33}$ Laboratoire d'Aérologie, Université de Toulouse, CNRS, UPS, Toulouse, France

${ }^{34}$ Bureau of Meteorology, Melbourne, Victoria, Australia

${ }^{35}$ Earth Observing Laboratory, National Center for Atmospheric Research, Boulder, CO, USA

${ }^{36}$ Alfred Wegener Institute, Helmholtz Centre for Polar and Marine Research, Potsdam, Germany

${ }^{37}$ Science Systems and Applications Inc., Greenbelt, MD, USA

${ }^{38}$ Atmospheric Research and Instrumentation Branch, National Institute for Aerospace Technology (INTA), Madrid, Spain

Correspondence to: Guanyu Huang (guanyu.huang@cfa.harvard.edu)

Received: 19 January 2017 - Discussion started: 15 February 2017

Revised: 25 May 2017 - Accepted: 29 May 2017 - Published: 13 July 2017

Abstract. We validate the Ozone Monitoring Instrument (OMI) Ozone Profile (PROFOZ) product from October 2004 through December 2014 retrieved by the Smithsonian Astrophysical Observatory (SAO) algorithm against ozonesonde observations. We also evaluate the effects of OMI row anomaly (RA) on the retrieval by dividing the dataset into before and after the occurrence of serious OMI RA, i.e., pre-RA (2004-2008) and post-RA (2009-2014). The retrieval shows good agreement with ozonesondes in the tropics and midlatitudes and for pressure $<\sim 50 \mathrm{hPa}$ in the high latitudes. It demonstrates clear improvement over the a priori down to the lower troposphere in the tropics and down to an average of $\sim 550(300) \mathrm{hPa}$ at middle (high) latitudes. In the tropics and midlatitudes, the profile mean biases (MBs) are less than $6 \%$, and the standard deviations (SDs) range from 5 to $10 \%$ for pressure $<\sim 50 \mathrm{hPa}$ to less than $18 \%(27 \%)$ in the tropics (midlatitudes) for pressure $>\sim 50 \mathrm{hPa}$ after applying OMI averaging kernels to ozonesonde data. The MBs of the stratospheric ozone column (SOC, the ozone column from the tropopause pressure to the ozonesonde burst pressure) are within $2 \%$ with SDs of $<5 \%$ and the MBs of the tropospheric ozone column (TOC) are within $6 \%$ with SDs of $15 \%$. In the high latitudes, the profile MBs are within $10 \%$ with SDs of $5-15 \%$ for pressure $<\sim 50 \mathrm{hPa}$ but increase to $30 \%$ with SDs as great as $40 \%$ for pressure $>\sim 50 \mathrm{hPa}$. The SOC MBs increase up to $3 \%$ with SDs as great as $6 \%$ and the TOC SDs increase up to $30 \%$. The comparison generally degrades at larger solar zenith angles (SZA) due to weaker signals and additional sources of error, leading to worse performance at high latitudes and during the midlatitude winter. Agreement also degrades with increasing cloudiness for pressure $>\sim 100 \mathrm{hPa}$ and varies with cross-track position, especially with large MBs and SDs at extreme off-nadir positions. In the tropics and midlatitudes, the post-RA comparison is considerably worse with larger SDs reaching $2 \%$ in the stratosphere and $8 \%$ in the troposphere and up to $6 \%$ in TOC. There are systematic differences that vary with latitude compared to the pre-RA comparison. The retrieval comparison demonstrates good long-term stability during the pre-RA period but exhibits a statistically significant trend of 0.14
$0.7 \%$ year $^{-1}$ for pressure $<\sim 80 \mathrm{hPa}, 0.7 \mathrm{DU}_{\text {year }}{ }^{-1}$ in SOC, and $-0.33 \mathrm{DU}_{\text {year }}{ }^{-1}$ in TOC during the post-RA period. The spatiotemporal variation of retrieval performance suggests the need to improve OMI's radiometric calibration especially during the post-RA period to maintain the long-term stability and reduce the latitude/season/SZA and cross-track dependency of retrieval quality.

\section{Introduction}

The Dutch-Finnish Ozone Monitoring Instrument (OMI) on board the NASA Aura satellite has been making useful measurements of trace gases including ozone and aerosols since October 2004. There are various retrieval algorithms to retrieve ozone profile and/or total ozone from OMI data (Bak et al., 2015), including two independent operational total ozone algorithms (Bhartia and Wellemeyer, 2002; Veefkind et al., 2006) and two ozone profile algorithms. Of the two ozone profile algorithms, one is the operational algorithm (OMO3PR) developed at KNMI (van Oss et al., 2001), and the other one is a research algorithm developed at Smithsonian Astrophysical Observatory (SAO) by (Liu et al., 2010b). Both algorithms retrieve ozone profile from the spectral region $270-330 \mathrm{~nm}$ using the optimal estimation method, but they differ significantly in implementation details including radiometric calibration, radiative transfer model simulation, a priori constraint, retrieval grids, and additional retrieval parameters. The SAO ozone profile retrieval algorithm was initially developed for Global Ozone Monitoring Experiment (GOME) data and was adapted to OMI data (Liu et al., 2010b). Total ozone column (OC), stratospheric ozone column (SOC), and tropospheric ozone column (TOC) can be directly derived from the retrieved ozone profile with retrieval errors in the range of a few Dobson units (DU) (Liu et al., 2006b, 2010a). This algorithm has been put into production in the OMI Science Investigator-led Processing System (SIPS), processing the entire OMI data record with an approximately 1-month delay. The ozone profile product titled PROFOZ is publicly available at the Aura Validation Data 
Center (AVDC) (https://avdc.gsfc.nasa.gov/index.php?site= 1389025893\&id=74). This long-term ozone profile product, with high spatial resolution and daily global coverage, constitutes a useful dataset to study the spatial and temporal distribution of ozone.

To effectively use the retrieval dataset, it is necessary to evaluate and understand its retrieval quality and long-term performance. Although validation of the ozone profile product (mostly earlier versions) has been partially performed against aircraft, ozonesonde, and microwave limb sounder (MLS) data, these evaluations are limited to certain time periods and/or spatial region and/or to only portion of the product (e.g., OC or TOC only) (Bak et al., 2013a; Hayashida et al., 2015; Lal et al., 2013; Liu et al., 2010a, b; Pittman et al., 2009; Sellitto et al., 2011; Wang et al., 2011; Yang et al., 2007; Ziemke et al., 2014). Additionally, the quality of ozone profile retrievals is very sensitive to the signal-to-noise ratio (SNR) of the radiance measurements as well as their radiometric calibration, which may degrade over time as shown in GOME and GOME-2 retrievals (Cai et al., 2012; Liu et al., 2007). Although OMI's optical degradation is remarkably small to within 1-2\% over the years, the SNR and the number of good spectral pixels (not flagged as bad/hot pixels) have been gradually decreasing over the years due to the expected charge-coupled device (CCD) degradation (Claas, 2014). Furthermore, the occurrence of row anomaly (RA), which affects level $1 \mathrm{~b}$ data at all wavelengths for particular viewing directions or cross-track positions and likely due to blocking objects in the optical path, started in June 2007 affecting a few positions. This effect abruptly worsened in January 2009, affecting approximately one third of the crosstrack positions (Kroon et al., 2011). The impacts of RA not only evolve with time but also vary over the duration of an orbit. Analysis indicates that radiances in the UV1 channels (shorter than $\sim 310 \mathrm{~nm}$ ) used in our retrievals might have been affected at all positions (Sergey Marchenko, personal communication, 2014) and are not adequately flagged for RA. Therefore, we need to evaluate the impacts of instrument degradation and especially RA on the temporal performance of our ozone profile product. Currently, we are planning an update of the ozone profile algorithm to maintain the long-term consistency of the product. The update will include empirical correction of systematic errors caused by the instrument degradation and RA as a function of time. Such correction also requires us to evaluate the long-term retrieval quality of our product.

To understand retrieval quality and the resulting spatial and temporal performance of our OMI product, we evaluate our data from October 2004 through December 2014 against available ozonesonde and MLS observations in two papers. This paper evaluates our ozone product including both ozone profiles and stratospheric and tropospheric ozone columns using ozonesonde observations with a focus on retrieval quality in the troposphere. More than 27000 ozonesonde profiles from both regular ozonesonde stations and field campaigns are used in this study to provide a comprehensive and global assessment of the long-term quality of our OMI ozone product. This paper is followed by the validation against collocated MLS data with a focus on the retrieval quality in the stratosphere (Huang et al., 2017, also submitted to this special issue).

This paper is organized as follows: Sect. 2 describes OMI retrievals and ozonesonde data. The validation methodology is introduced in Sect. 3. Section 4 presents results, analysis, and discussions regarding the OMI and ozonesonde comparisons. Section 5 summarizes and concludes this study.

\section{OMI and ozonesonde datasets}

\subsection{OMI and OMI ozone profile retrievals}

OMI is a Dutch-Finnish nadir-viewing push-broom UVvisible instrument aboard the NASA Earth Observing System (EOS) Aura satellite that was launched into a sunsynchronous orbit in July 2004. It measures backscattered radiances in three channels covering the $270-500 \mathrm{~nm}$ wavelength range (UV1: 270-310 nm; UV2: 310-365 nm; visible: $350-500 \mathrm{~nm}$ ) at spectral resolutions of $0.42-0.63 \mathrm{~nm}$ (Levelt et al., 2006). Measurements across the track are binned to 60 positions for UV2 and visible channels and 30 positions for the UV1 channels due to the weaker signals. This results in daily global coverage with a nadir spatial resolution of $13 \mathrm{~km} \times 24 \mathrm{~km}$ (along $\times$ across track) for UV2 and visible channels and $13 \mathrm{~km} \times 48 \mathrm{~km}$ for the UV1 channel.

The SAO OMI ozone profile algorithm was adapted from the GOME ozone profile algorithm (Liu et al., 2005) to OMI and was initially described in detail in Liu et al. (2010b). Profiles of partial ozone columns are retrieved at 24 layers, $\sim 2.5 \mathrm{~km}$ for each layer, from the surface to $\sim 60 \mathrm{~km} \mathrm{us}-$ ing OMI radiance spectra in the spectral region $270-330 \mathrm{~nm}$ with the optimal estimation technique. In addition to the $\mathrm{OC}$, SOC and TOC can be directly derived from the retrieved ozone profile with the use of tropopause (defined based on the lapse rate) from the daily National Center for Environmental Protection (NCEP) reanalysis data. The retrievals are constrained with month- and latitude-dependent climatological a priori profiles derived from 15-year ozonesonde and SAGE/MLS data (McPeters et al., 2007) with considerations of OMI random noise errors. OMI radiances are precalibrated based on 2 days of average radiance differences in the tropics between OMI observations and simulations with zonal mean MLS data for pressure less than $215 \mathrm{hPa}$ and climatological ozone profile for pressure greater than $215 \mathrm{hPa}$. This "soft calibration" varies with wavelength and cross-track positions but does not depend on space and time.

The current algorithm of our SAO OMI ozone product that is used in this paper was briefly described in Kim et al. (2013). The radiative transfer calculations have been improved through the convolution of simulated radiance spectra 
at high resolutions rather than effective cross sections, which is done by interpolation from calculation at selected wavelengths assisted by weighting function. In addition, four spatial pixels along the track are co-added to speed up production processes at a nadir spatial resolution of $52 \mathrm{~km} \times 48 \mathrm{~km}$. Meanwhile, minimum measurement errors of 0.4 and $0.2 \%$ are imposed in the spectral ranges $270-300$ and $300-330 \mathrm{~nm}$, respectively, to stabilize the retrievals. The use of floor errors typically reduces the degree of freedom for signals (DFS) and increases retrieval errors. Compared to the initial retrievals, the average total, stratospheric, and tropospheric DFS decrease by $0.49,0.27$, and 0.22 , respectively, and the mean retrieval errors in OC, SOC, and TOC increase by 0.6 , 0.5 , and $1.2 \mathrm{DU}$, respectively. The corresponding changes to the retrievals are generally within retrieval uncertainties except for a systematic increase in tropospheric ozone at solar zenith angles (SZAs) larger than $\sim 75^{\circ}$, where the TOC increases to $\sim 12 \mathrm{DU}$. Validation against ozonesonde data indicates that this TOC increase at large SZA makes the retrieval worse. Therefore retrieved tropospheric ozone at such large SZA should not be used, but the retrieved total ozone still shows good quality (Bak et al., 2015).

For current products, retrievals contain $\sim 5.5-7.4 \mathrm{DFS}$, with 4.6-7.3 in the stratosphere and 0-1.2 in the troposphere. Vertical resolution varies generally from $7-11 \mathrm{~km}$ in the stratosphere to $10-14 \mathrm{~km}$ in the troposphere, when there is adequate retrieval sensitivity to the tropospheric ozone. Retrieval random noise errors (i.e., precisions) typically range from $0.6-2.5 \%$ in the middle stratosphere to approximately $12 \%$ in the lower stratosphere and troposphere. The solution errors, dominated by smoothing errors, vary generally from $1-7 \%$ in the middle stratosphere to $7-38 \%$ in the troposphere. The solution errors in the integrated OC, SOC, and TOC are typically in the few DU range. Errors caused by the forward model and forward model parameter assumptions are generally much smaller than the smoothing error (Liu et al., 2005). The main sources of these errors include systematic errors in temperature and cloud-top pressure. Systematic measurement errors are the most difficult to estimate, mostly due to lack of full understanding of the OMI instrument calibration.

Certain cross-track positions in OMI data have been affected by RA since June 2007 (Kroon et al., 2011). Loose thermal insulating material in front of the instrument's entrance slit is believed to block and scatter light, causing measurement error. The anomaly affects radiance measurements at all wavelengths for specific cross-track viewing directions that are imaged to CCD rows. Initially, the anomaly only affected a few rows. But since January 2009, the anomaly has spread to other rows and shifted with time. The RA also shows slight differences among different spectral channels, and varies during the duration of an orbit. Pixels affected by the RA are flagged in the level $1 \mathrm{~b}$ data. The science team suggested that they are not be used in research. For data before 2009 , the RA flagging is not applied in the processing.
Pixels seriously affected by RA will typically show enhanced fitting residuals. The algorithm was updated to use RA flagging in the UV1 channel and was used to process the data starting from 2009. If a pixel is flagged as an RA then it is subsequently not retrieved to speed up the processing, with the exception of the cross-track position 24 , which is still retrieved due to reasonably good fitting. It should be noted that the retrieval quality of those non-flagged pixels may still be affected by the RA because of the different RA flagging in the UV1 and UV2, the lack of RA flagging before 2009, and inadequacy of the RA flagging.

To screen out OMI profiles for validation, we only use OMI ozone profiles meeting the following criteria based on three filtering parameters: (1) nearly clear-sky scenes with effective cloud fraction less than 0.3 ; (2) cross-track positions between 4 and 27 due to the relatively worse quality and much larger footprint size of the off-nadir pixels beyond this range; (3) SZA should be less than $75^{\circ}$ due to very limited retrieval sensitivity to tropospheric ozone and the aforementioned positive biases. The selection and justification of these criteria will be discussed in Sects. 2.1.2-4.1.4, in which we will use all OMI pixels of each filtering parameter when evaluating retrieval quality as a function of that specific parameter. The fitting quality of each retrieval is shown in the fitting RMS (root mean square of the fitting residuals relative to the assumed measurement errors). The mean fitting RMS including both UV1 and UV2 channels has been increasing with time as shown in Fig. 1. This is primarily due to the increase of fitting residuals in UV1 caused by the instrument degradation and RA since the fitting residuals of UV2 only slightly increase with time. As aforementioned, the retrieval information of stratospheric and tropospheric ozone mainly comes from UV1 and UV2, respectively. Consequently, retrievals in the troposphere, the focus of this paper, are less impacted by the increasing fitting RMS. However, to apply consistent filtering in validation against both ozonesonde in this study and MLS data in the companion paper (Huang et al., 2017), we set the RMS threshold based on the overall fitting RMS and select retrievals with fitting RMS smaller than the sum of monthly mean RMS and its $2 \sigma$ (i.e., standard deviations (SDs) of fitting RMS).

\subsection{Ozonesondes}

The balloon-borne ozonesonde is a well-established technique to observe the ozone profile from the surface to $\sim 35 \mathrm{~km}$ with vertical resolution of $\sim 100-150 \mathrm{~m}$ and approximately $3-5 \%$ precision and 5-10\% accuracy (Deshler et al., 2008; Johnson, 2002; Komhyr, 1986; Komhyr et al., 1995; Smit et al., 2007). Ozonesonde data have been widely used in the studies of stratospheric ozone, climate change, tropospheric ozone, and air quality, as well as the validation of satellite observations (Huang et al., 2015; Kivi et al., 2007; Thompson et al., 2015; Wang et al., 2011). However, the accuracy of ozonesonde observations depends on data pro- 


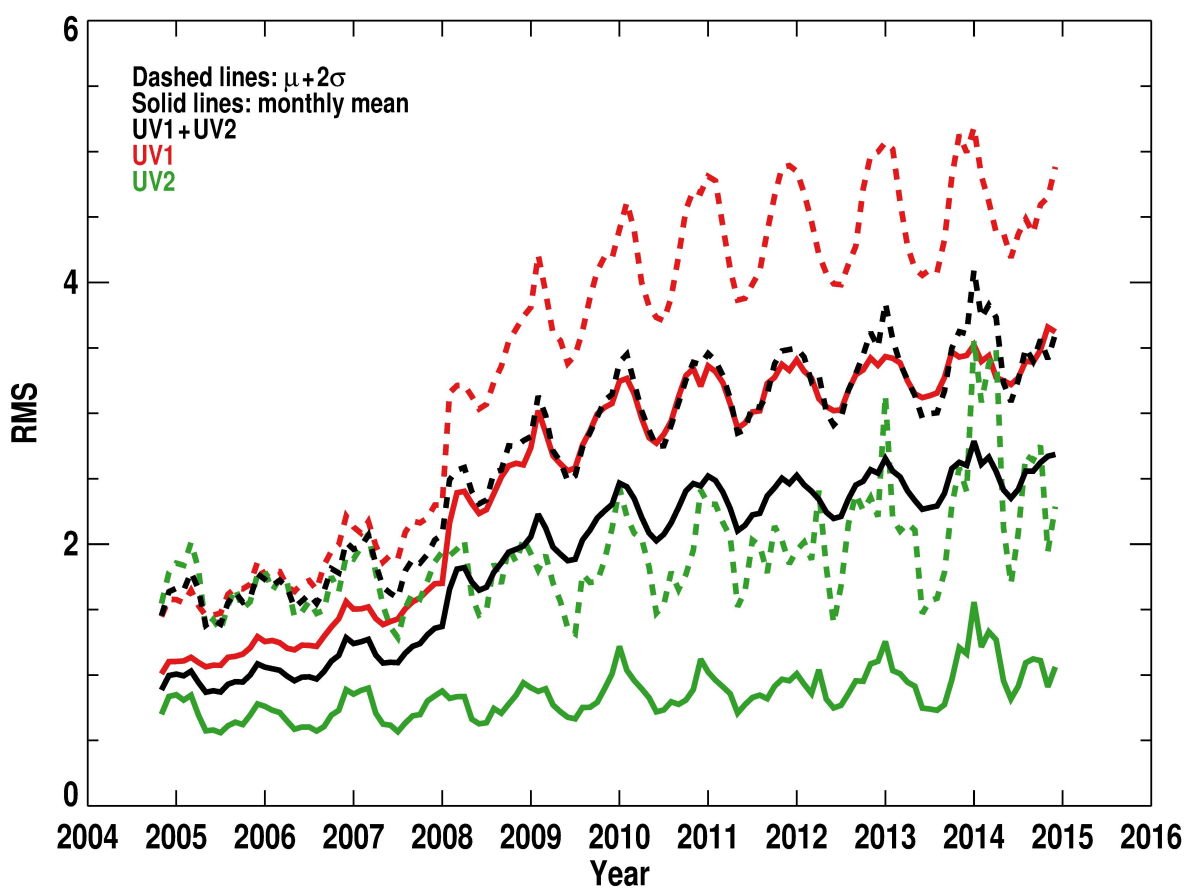

Figure 1. Variation of monthly mean OMI RMS (defined as root mean square of the ratio of radiance residuals to assumed radiance errors). The dashed and solid lines represent, respectively, the monthly mean RMS and the sum of monthly mean plus its two standard deviations that is set as the RMS threshold for data screening.

cessing technique, sensor solution, and instrument type and other factors. Consequently, station-to-station biases may occur in ozonesonde measurements and could be as great as $10 \%$ (Thompson et al., 2007c; Worden et al., 2007).

A decade (2004-2014) of global ozonesonde data with locations shown in Fig. 2, are utilized in this study to validate our OMI ozone profile product. Most of our ozonesonde data were obtained from the AVDC archive. It contains routine launches from ozonesonde stations, mostly weekly and occasionally two to three times a week at some stations. It also collects launches from field campaigns, for instance IONS 06 (INTEX-B Ozone Network Study 2006) and ARCIONS (Arctic Intensive Ozonesonde Network Study) (http://croc. gsfc.nasa.gov/arcions/) (Tarasick et al., 2010; Thompson et al., 2008). Data not available at AVDC are obtained from other archives such as the World Ozone and Ultraviolet Radiation Data Center (WOUDC) (http://woudc.org/) and the Southern Hemisphere Additional Ozonesondes (SHADOZ) (Thompson et al., 2007a, b), as well as archives of recent field campaigns including DISCOVER-AQ (Deriving Information on Surface Conditions from Column and Vertically Resolved Observations Relevant to Air Quality, http: //discover-aq.larc.nasa.gov/) (Thompson et al., 2015) and SEACR $^{4} \mathrm{~S}$ (Studies of Emissions and Atmospheric Composition, Clouds and Climate Coupling by Regional Surveys, https://espo.nasa.gov/home/seac4rs) (Toon et al., 2016). Almost all of the ozonesonde data in this study were obtained from electrochemical concentration cell (ECC) ozonesondes, which is based on the oxidation reaction of ozone with potassium iodide (KI) in solution. The exceptions are Hohenpeissenberg station in Germany that uses Brewer-Mast (BM) ozonesondes, the New Delhi, Poona, and Trivandrum stations that use Indian ozonesondes, and four Japanese stations (i.e., Sapporo, Tsukuba, Naha, and Syowa) that switched from KC ozonesondes to ECC ozonesondes during late 2008 and early 2010. These types of ozonesondes have been reported to have larger uncertainties than ECC ozonesondes (Hassler et al., 2014; Liu et al., 2013; WMO, 1998).

To avoid using anomalous profiles, we screen out ozonesondes that burst at pressure exceeding $200 \mathrm{hPa}$, ozone profiles with gaps greater than $3 \mathrm{~km}$, more than $80 \mathrm{DU}$ TOC, or less than $100 \mathrm{DU}$ SOC. In the SOC comparison, we also filter measurements that do not reach $12 \mathrm{hPa}$. Some ozonesonde data used in this paper (e.g. WOUDC data) are provided with a correction factor $(\mathrm{CF})$ derived by normalizing the integrated ozone column (appended with ozone climatology above burst altitude) to the coincident total ozone column measured by a Dobson or Brewer instrument to account for uncertainties mainly from the pump efficiency especially near the top of the profiles. The CF is also included in our screening processes. If the $\mathrm{CF}$ is available, we select ozonesonde profiles with the $\mathrm{CF}$ in the range of 0.85 to 1.15 to filter profiles that require too much correction and apply the correction. Finally, a small number of obviously erroneous profiles are visually examined and rejected. 


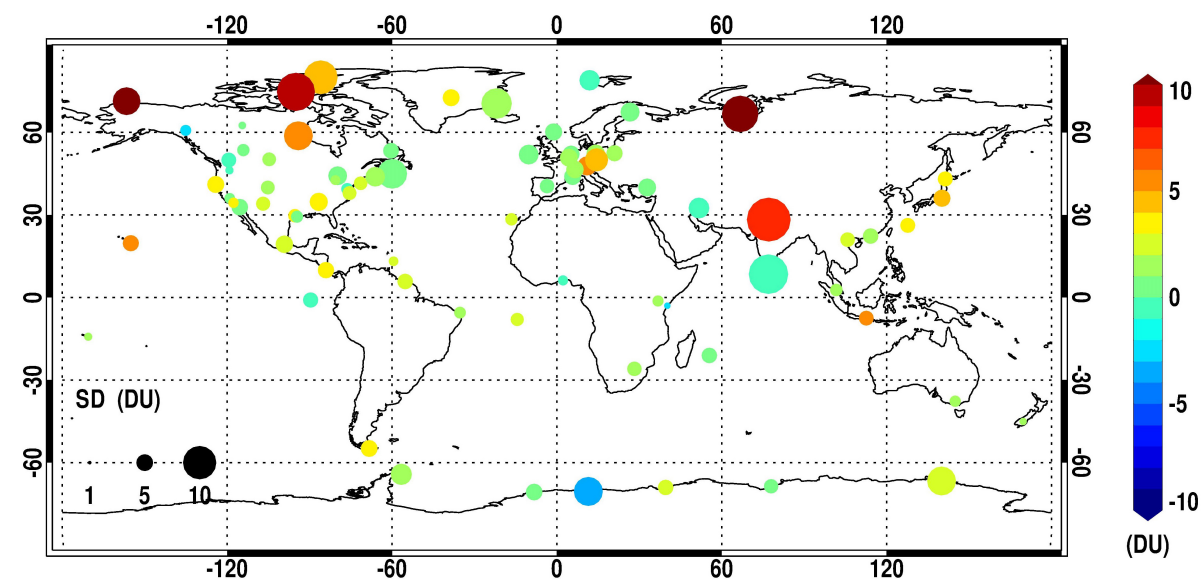

Figure 2. The distribution of ozonesonde stations in this study. The color represents the mean biases between OMI and ozonesonde tropospheric ozone columns (TOCs) at each station (if the number of OMI and ozonesonde pairs is more than 10), and the dot size represents the standard deviation.

\section{Comparison methodology}

Previous studies on the validation of satellite observations used a range of coincidence criteria. Wang et al. (2011) set a $100 \mathrm{~km}$ radius and $3 \mathrm{~h}$ time difference as coincidence criteria. Kroon et al. (2011) applied coincidence criteria of $\pm 0.5^{\circ}$ for both latitude and longitude and $12 \mathrm{~h}$. In this paper, we determine our coincident criteria based on the balance between finding most coincident OMI-ozonesonde pairs to minimize differences due to spatiotemporal samplings and finding a sufficient number of pairs for statistical analysis. For each screened ozonesonde profile, we first select all filtered OMI data within $\pm 1^{\circ}$ latitude, $\pm 3^{\circ}$ longitude, and $\pm 6 \mathrm{~h}$ and then find the nearest OMI retrieval within $100 \mathrm{~km}$ from the ozonesonde station to perform the validation on the individual profile basis.

Ozonesondes have much finer vertical resolution than OMI retrievals. To account for the different resolutions, ozonesonde profiles are first integrated into the corresponding OMI vertical grids and then degraded to the OMI vertical resolution by using the OMI retrieval averaging kernels (AKs) and a priori ozone profile based on the following equation:

$\hat{x}=x_{\mathrm{a}}+\mathbf{A}\left(x-x_{\mathrm{a}}\right)$,

where $x$ is the ozonesonde profile integrated into the OMI grid, $\hat{x}$ is the retrieved ozone profile if the ozonesonde is observed by OMI, $\mathbf{A}$ is the OMI AK matrix, and $x_{\mathrm{a}}$ is the OMI a priori ozone profile. We refer to this retrieval as "convolved ozonesonde profile", which is a reconstruction of ozonesonde profile with OMI retrieval vertical resolution and sensitivity. Missing ozone profiles above ozonesonde burst altitude are filled with OMI retrievals. The convolution process essentially removes OMI smoothing errors and the impacts of a priori from the comparison so that OMI-ozonesonde differences are mainly due to OMI-ozonesonde measurement precision, spatiotemporal sampling differences, and other errors. However, in the regions and altitudes where OMI has low retrieval sensitivity, the comparisons can show good agreement because both the retrieval and convolved ozonesonde approach the a priori profile. To overcome the limitation of such a comparison, we also compare with unconvolved ozonesonde profiles since it indicates how well the retrievals can represent the actual ozonesonde observations (i.e., smoothing errors are included as part of retrieval errors). In addition, we also compare OMI a priori and convolved/unconvolved ozonesonde profiles to indicate the retrieval improvement over the a priori.

For consistent calculations of TOC and SOC from the OMI-ozonesonde data, the tropopause pressure included in the OMI retrieval and ozonesonde burst pressure (required to be less than $12 \mathrm{hPa}$ or above $\sim 30 \mathrm{~km}$ ) are used as the proper boundaries. The TOC is integrated from the surface to the tropopause, and the SOC is not the total stratospheric ozone column but rather the ozone column integrated from the tropopause pressure to the ozonesonde burst pressure.

The relative profile difference is calculated as (OMI - sonde) / OMI a priori $\times 100 \%$ in the present comparison with ozonesonde and with MLS in the companion paper. Choosing OMI a priori rather than MLS/ozonesonde is to avoid unrealistic statistics skewed by extremely small values in the reference data especially in the MLS retrievals of upper troposphere and lower stratosphere ozone (Liu et al., 2010a). Unlike the profile comparison, ozonesonde-OMI SOC-TOC values are used in the denominator in the computation of relative difference. To exclude remaining extreme outliers in the comparison statistics, values that exceed $3 \sigma$ from the mean differences are filtered.

After applying the OMI-ozone filtering and coincident criteria, approximately 10500 ozonesonde profiles are used in the validation. We performed the comparison for five latitude 
bands: northern high latitudes $\left(60-90^{\circ} \mathrm{N}\right)$, northern midlatitudes $\left(30-60^{\circ} \mathrm{N}\right)$, tropics $\left(30^{\circ} \mathrm{S}-30^{\circ} \mathrm{N}\right)$, southern midlatitudes $\left(60-30^{\circ} \mathrm{S}\right)$, and southern high latitudes $\left(90-60^{\circ} \mathrm{S}\right)$ to understand the latitudinal variation of the retrieval performance. We investigated the seasonal variations of the comparisons mainly at northern midlatitudes where ozone retrieval shows distinct seasonality and there are adequate coincidence pairs. To investigate the RA impacts on OMI retrievals, we contrasted the comparison before (2004-2008, i.e., pre-RA) and after (2009-2014, i.e., post-RA). Although we filter OMI data based on cloud fraction, cross-track position, and SZA in the final evaluation of our retrievals against ozonesonde observations as shown in Sect. 4.1.1., we conduct the comparison as a function of these parameters using coincidences at all latitude bands to show how these parameters affect the retrieval quality as shown in the Sect. 4.1.24.1.4. In these evaluations, the filtering of OMI data based on cloud fraction, cross-track position, and SZA, respectively, are switched off. Approximately 15000 additional ozonesonde profiles are used in this extended evaluation. To evaluate the long-term performance of our ozone profile retrievals, we analyze the monthly mean biases (MBs) of the OMI-ozonesonde differences as a function of time using coincidences in the $60^{\circ} \mathrm{S}-60^{\circ} \mathrm{N}$ region and then derive a linear trends over the entire period as well as the pre-RA and postRA periods.

\section{Results and discussions}

\subsection{Comparison of ozonesonde and OMI profiles}

\subsubsection{Ozone profile differences}

Comparisons of ozone profiles between OMI-a priori and ozonesondes with and without applying OMI AKs for the 10-year period (2004-2014) are shown in the left panels of Fig. 3. The MBs and SDs vary spatially with altitude and latitude. Vertically, the SD typically maximizes in the upper troposphere and lower stratosphere (UTLS) in all latitude bands due to significant ozone variability and a priori uncertainty. Bak et al. (2013b) showed that the use of tropopause-based (TB) ozone profile climatology with NCEP Global Forecast System (GFS) daily tropopause pressure can significantly improve the a priori and eventually reduce the retrieval uncertainty. Consequently, the SDs of OMI-sonde differences in the UTLS at middle and high latitudes can be reduced through reducing the retrieval uncertainties in a future version of the algorithm that uses the TB climatology. Latitudinally, the agreement is better in the tropics and becomes worse at higher latitudes. The patterns are generally similar in the Northern and Southern hemispheres. The MBs between OMI and ozonesonde are within $\sim 6 \%$ with AKs and $10 \%$ without $\mathrm{AKs}$ in the tropics and the middle latitudes. Large changes in the biases between MBs with and without
AKs occur in the tropical troposphere where the bias differences reach $10 \%$. The MBs increase to $20-30 \%$ at high latitudes consistently with large oscillation from $\sim-20-30 \%$ at $\sim 300 \mathrm{hPa}$ to $+20 \%$ near the surface both with and without the application of AKs. At pressure $<50 \mathrm{hPa}$, the SDs for comparisons with OMI AKs are typically $5-10 \%$ at all latitudes except for the $90-60^{\circ} \mathrm{S}$ region. For pressure $>50 \mathrm{hPa}$, the SDs are within 18 and $27 \%$ in the tropics and middle latitudes, respectively, but increase to $40 \%$ at higher latitudes. The SDs for comparison without applying OMI AKs, i.e., including OMI smoothing errors in the OMI-ozonesonde differences, typically increase up to $5 \%$ for pressure $<50 \mathrm{hPa}$ but increase up to $15-20 \%$ for pressure $>\sim 50 \mathrm{hPa}$. The smoothing errors derived from root square differences of the MBs with and without OMI AKs are generally consistent with the retrieval estimate from the optimal estimation.

The improvements of OMI over the climatological (a priori) profiles can be reflected in the reduction of MBs and SDs in the comparisons between ozonesondes and OMI retrievals and between ozonesondes and a priori. The retrieval improvements in the MBs are clearly shown in the tropics and at $\sim 100 \mathrm{hPa}$ pressure in the middle latitudes. At high latitudes, the MBs and corresponding oscillations in the troposphere are much larger than these in the a priori comparison, suggesting that these large biases are mainly caused by other systematic measurements errors at high latitudes (larger SZAs and thus weaker signals). As can be seen from the reduction of SDs, OMI retrievals show clear improvements over the a priori at pressure $<300 \mathrm{hPa}$. For pressure $>300 \mathrm{hPa}$, the retrieval improvements vary with latitudes. There are consistent retrieval improvements throughout the surface $300 \mathrm{hPa}$ layer in the tropics and only the $550-300 \mathrm{hPa}$ layer at middle latitude, while there is no retrieval improvement over the a priori for $>300 \mathrm{hPa}$ at high latitudes. The failure to improve the retrieval over a priori in part of the troposphere at middle and high latitudes is caused by several factors. They are the inherent reduction in retrieval sensitivity to lower altitudes at larger SZAs as a result of reduced photon penetration into the atmosphere, unrealized retrieval sensitivity arising from retrieval interferences with other parameters (e.g., surface albedo) as discussed in Liu et al. (2010b), and the use of floor noise of $0.2 \%$ that underestimates the actual OMI measurement SNR. In addition, the a priori ozone error in the climatology is quite small since the SDs of the differences between the a priori and ozonesonde without AKs are typically less than $20 \%$ in the lower troposphere for middle and high latitudes, which also makes it more difficult to improve over the a priori comparison.

The right column of Fig. 3 shows the comparisons between OMI retrievals and ozonesondes convolved with OMI AKs in the pre-RA and post-RA periods, respectively. In the tropics and midlatitudes, the pre-RA comparison is better than the post-RA comparison, with SDs smaller by up to $\sim 8 \%$ at most altitudes especially in the troposphere. The pre-RA comparison also shows smaller biases near $\sim 300 \mathrm{hPa}$ at mid- 


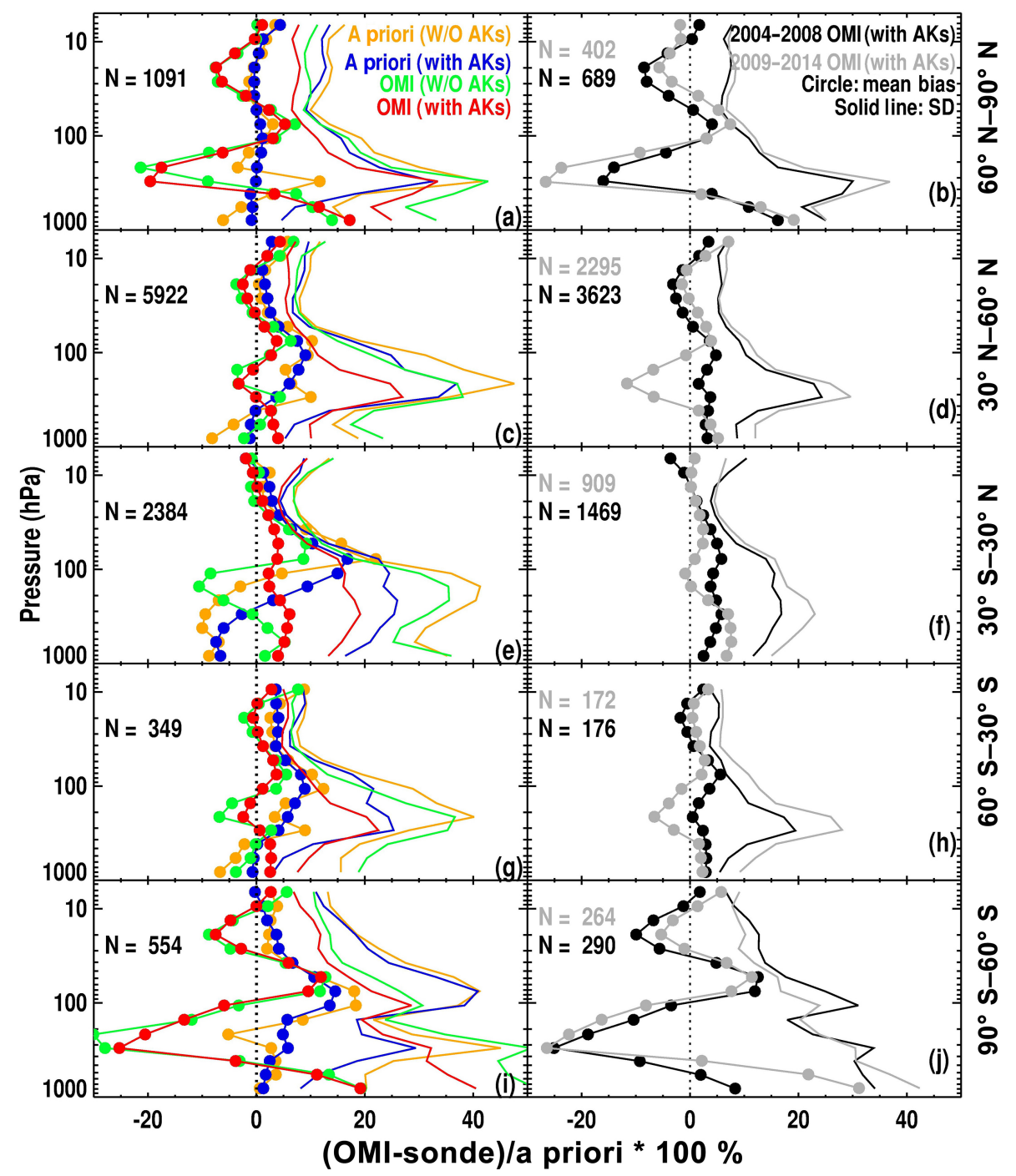

Figure 3. Mean relative biases in ozone (line with circles) and corresponding standard deviations (solid lines) between OMI retrieval-a priori and ozonesondes with and without (W/O) applying OMI retrieval averaging kernels (i.e., with AKs and without AKs in red and green for comparing retrievals and in blue and yellow for comparing a priori) for five different latitude bands. The left panels show the comparison using 10 years of OMI data (2004-2014), and the right panels show the comparison between OMI retrieval and ozonesonde with OMI AKs for before and after the occurrence of serious OMI row anomaly (RA), i.e., pre-RA (2004-2008) in black and post-RA (2009-2014) in gray. The number $(N)$ of OMI-ozonesonde coincidences used in the comparison is indicated in the legends.

dle latitudes while the post-RA comparison exhibits negative biases reaching $8-12 \%$. At high latitudes, the pre-RA period does not show persistent improvement during the post-RA period. The pre-RA comparison shows slightly smaller SDs at most altitudes and smaller negative biases by $10 \%$ around $300 \mathrm{hPa}$ in the northern high latitudes and smaller positive biases by $20 \%$ near the surface in the southern high latitudes. The worse results during the post-RA period are caused by increasingly noisy OMI measurements with smaller SNR and the additional radiometric biases made by the RA, which vary with space and time. The smaller SDs at some altitudes of high latitudes may reflect a combination of ozone variation, uneven distribution of ozonesondes with varying uncer- tainty at different stations, and cancellation of radiometric errors by the RA.

As seen from the number of OMI-ozonesonde coincidences shown in Fig. 3, the northern midlatitudes and the tropics have sufficient coincidences to validate the retrievals as a function of season. In the tropics, the retrieval comparison does exhibit little seasonality as expected (not shown). Figure 4 shows the comparison similar to Fig. 3c for each individual season at northern middle latitudes. The comparison results are clearly dependent on season with different altitude-dependent bias patterns, and with the smallest SDs in the summer (except for the MBs) and the worst SDs in the winter. This indicates the general best retrieval sensitiv- 


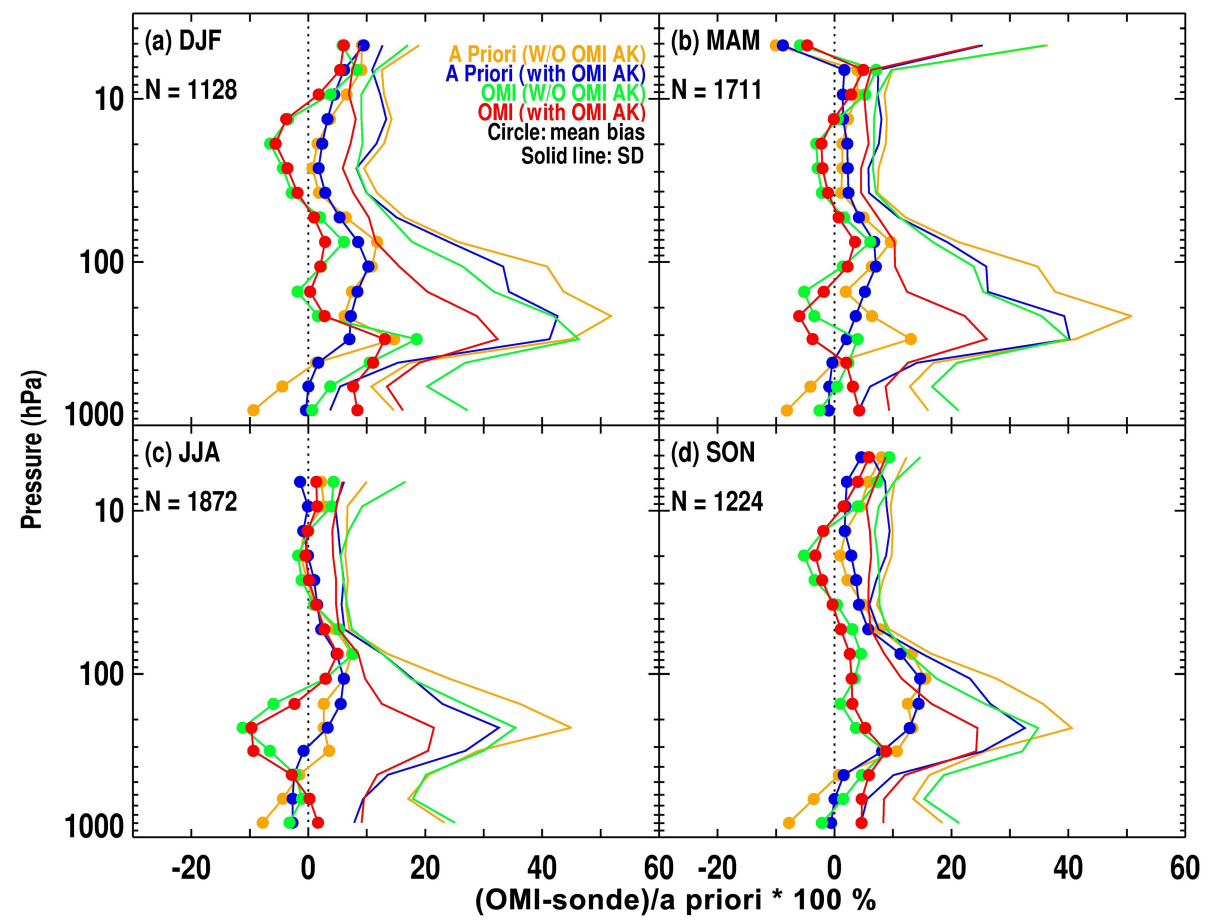

Figure 4. Same as Fig. $3 \mathrm{c}$ but for each individual season at $30-60^{\circ} \mathrm{N}$.

ity to lower tropospheric ozone during the summer as a result of small SZAs and stronger signals and worst retrieval sensitivity during the winter as a result of large SZAs and weaker signals. The MBs with and without AKs at $300 \mathrm{hPa}$ vary from $\sim 12 \%$ in the winter to $-10 \%$ in the summer. The overall MBs are the smallest during the spring, within $6 \%$, but the MBs at pressure $<50 \mathrm{hPa}$ are the best during the summer. The maximum SDs vary from $31 \%$ in the winter to $20 \%$ in the summer. Also, the retrieval in the summer shows the most improvements in terms of reduction in SDs over the a priori in the lower troposphere at all tropospheric layers except for the bottom layer, while the retrievals during other seasons show the improvement over a priori only above the lowermost two or three layers. The seasonal variation of retrieval quality is partially caused by the seasonal variations of the retrieval sensitivity and ozone variability. Bak et al. (2013b) showed that the use of TB ozone climatology with daily NCEP GFS tropopause pressure can significantly reduce the seasonal dependence of the comparison with ozonesondes. In addition, radiometric calibration errors such as those caused by stray light and RA also contribute to the seasonal variation of retrieval quality.

\subsubsection{SZA dependence}

The SZA of low earth orbit (LEO) satellite observation varies latitudinally and seasonally; therefore the SZA dependence of the retrieval can cause latitude- and season-dependent retrieval biases. SZA is one of the main drivers that affect re- trieval sensitivity especially to tropospheric ozone. At large SZA, the measured backscattered signal becomes weak due to weak incoming signal and long path length; the retrieval sensitivity to the tropospheric ozone decreases due to reduced photon penetration to the troposphere. In addition, measurements are subject to relatively larger radiometric errors such as those from stray light and as a result of weaker signal, and radiative transfer calculations can lose accuracy at larger SZA (Caudill et al., 1997).

Figure 5 gives the MBs and SDs of differences between OMI and ozonesondes (with OMI AKs) in a function of SZAs. We can see that retrieval performance generally becomes worse at large SZA. The SD typically increases with SZA especially at pressure $>300 \mathrm{hPa}$. At SZA larger than $75^{\circ}$, the $\mathrm{SD}$ at $\sim 300 \mathrm{hPa}$ increases to greater than $\sim 45 \%$. The variation of MBs with SZA is more complicated. We see generally larger positive biases at larger SZA in the troposphere with $>20 \%$ biases at SZA larger than $75^{\circ}$. The MBs near $\sim 30 \mathrm{hPa}$ become more negative at larger SZAs. There is a strip of positive biases of $\sim 10 \%$ that slightly decreases in pressure from $\sim 50 \mathrm{hPa}$ at low $\mathrm{SZA}$ to $\sim 10 \mathrm{hPa}$ at large SZA; it might be due to some systematic radiometric biases that can affect ozone at different altitudes varying with SZA. Because of the clear degradation of the retrieval quality at large SZA, we set the SZA filtering threshold of $75^{\circ}$ to filter OMI data. 


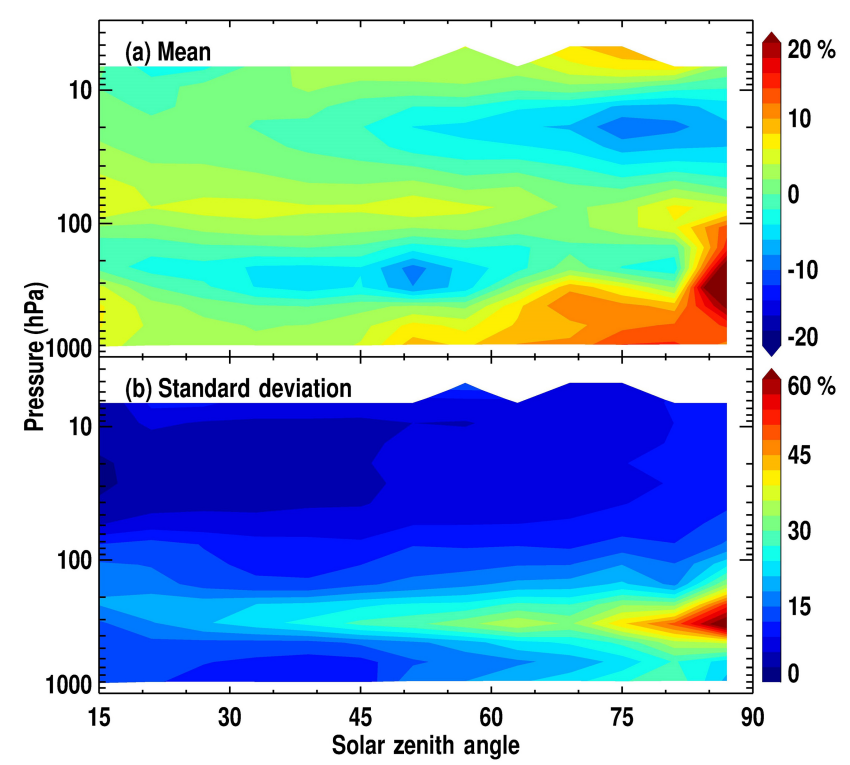

Figure 5. Mean relative biases in ozone (a) and standard deviations (b) of the differences between OMI and ozonesonde convolved with OMI AKs as a function of solar zenith angle using all OMI-ozonesonde coincidences during 2004-2014.

\subsubsection{Cloud fraction dependence}

The presence of cloud affects retrieval sensitivity since clouds typically reduce sensitivity to ozone below clouds and increase sensitivity to ozone above clouds. The accuracy of ozone retrievals is sensitive to the uncertainties of cloud information and cloud treatment (Antón and Loyola, 2011; Bak et al., 2015; Liu et al., 2010a). Our OMI ozone algorithm assumes clouds as Lambertian surfaces with optical centroid cloud pressure from the OMI Raman cloud product (Vasilkov et al., 2008), and partial clouds are modeled using independent pixel approximation such that the overall radiance is the sum of clear and cloudy radiances weighted by the effective cloud fraction. The cloud albedo is assumed to be $80 \%$ and is allowed to vary $(>80 \%)$ with the effective cloud fraction.

Figure 6 gives the influences of effective cloud fraction on the comparisons between OMI and ozonesonde observations convolved with OMI AKs. The MBs and SDs do not change much with cloud fraction for pressure $<100 \mathrm{hPa}$, and typically increase with the increase of cloud fraction for pressure $>100 \mathrm{hPa}$. The MBs at pressure $>100 \mathrm{hPa}$, especially greater $\sim 300 \mathrm{hPa}$, increase to more than $10 \%$ with cloud fraction greater than $\sim 0.3$. This indicates that the cloud fractions have small impacts on the stratospheric retrievals but large impacts on the tropospheric retrievals as expected. Some of the variation with cloud fraction such as negative biases near $\sim 300 \mathrm{hPa}$ at cloud fraction of $\sim 0.4$ and the decreases of positive biases at $\sim 50 \mathrm{hPa}$ for cloud fraction greater than $\sim 0.8$ may be partially related to the uncertainties of the cloud parameters. The chosen filtering thresh-

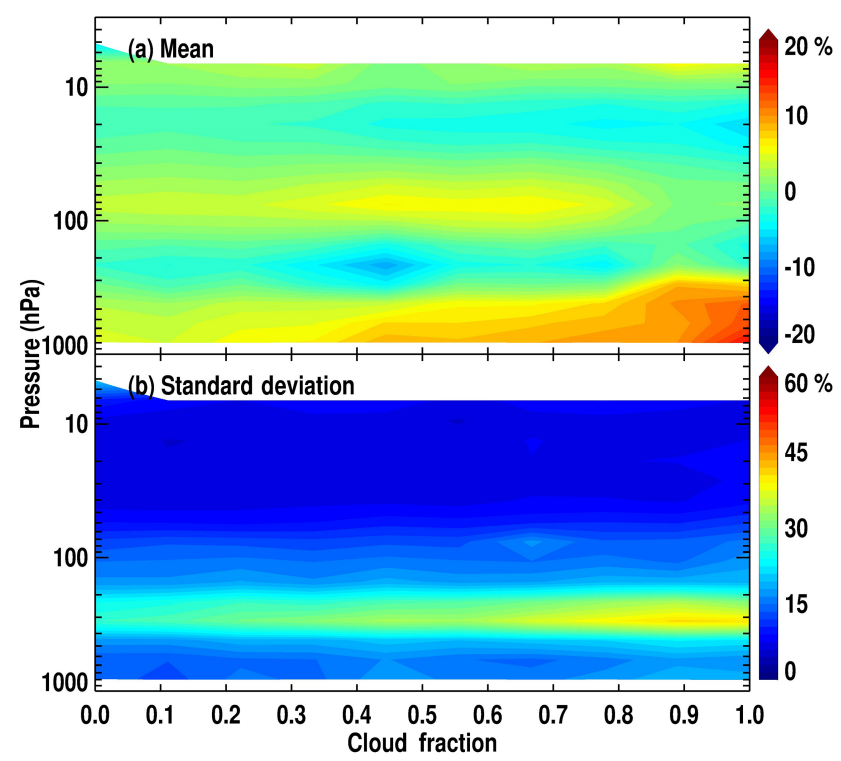

Figure 6. Same as Fig. 5 but as a function of cloud fraction.

old of 0.3 in cloud fraction is a tradeoff between validating OMI data with adequate retrieval sensitivity to tropospheric ozone and finding adequate number of OMI-ozonesonde coincidences.

\subsubsection{Cross-track position dependence}

The OMI swath is divided into 30 cross-track pixels at the UV1 spatial resolution of our product. Each cross-track position is measured by a different part of the CCD detector, i.e., essentially a different instrument. Radiometric calibration coefficients of the instrument are characterized during pre-launch only at selected CCD column pixels and then interpolated to other columns, causing variation in the radiometric calibration performance across the CCD detector. This in turn causes cross-track-dependent biases in the calibrated radiance (Liu et al., 2010b), which therefore causes stripping in almost all the OMI data products if no de-striping procedure is applied. Our retrieval algorithm has included a first-order empirical correction independent of space and time to remove the cross-track variability (Liu et al., 2010b). However, residual dependence on cross-track position remains and the radiometric calibration at different position can degrade differently with time (e.g., the RA impact). In addition, the viewing zenith angle ranges from $\sim 0$ to $\sim 70^{\circ}$ and the footprint area increases by approximately an order of magnitude from nadir to the first/last position. So the varying viewing zenith angle causes the variation of retrieval sensitivities and atmospheric variabilities within varying footprint areas may also cause additional cross-track dependence in the retrieval performance.

Figure 7 provides the MBs and SDs of the differences between OMI and ozonesonde convolved with OMI AKs as a 


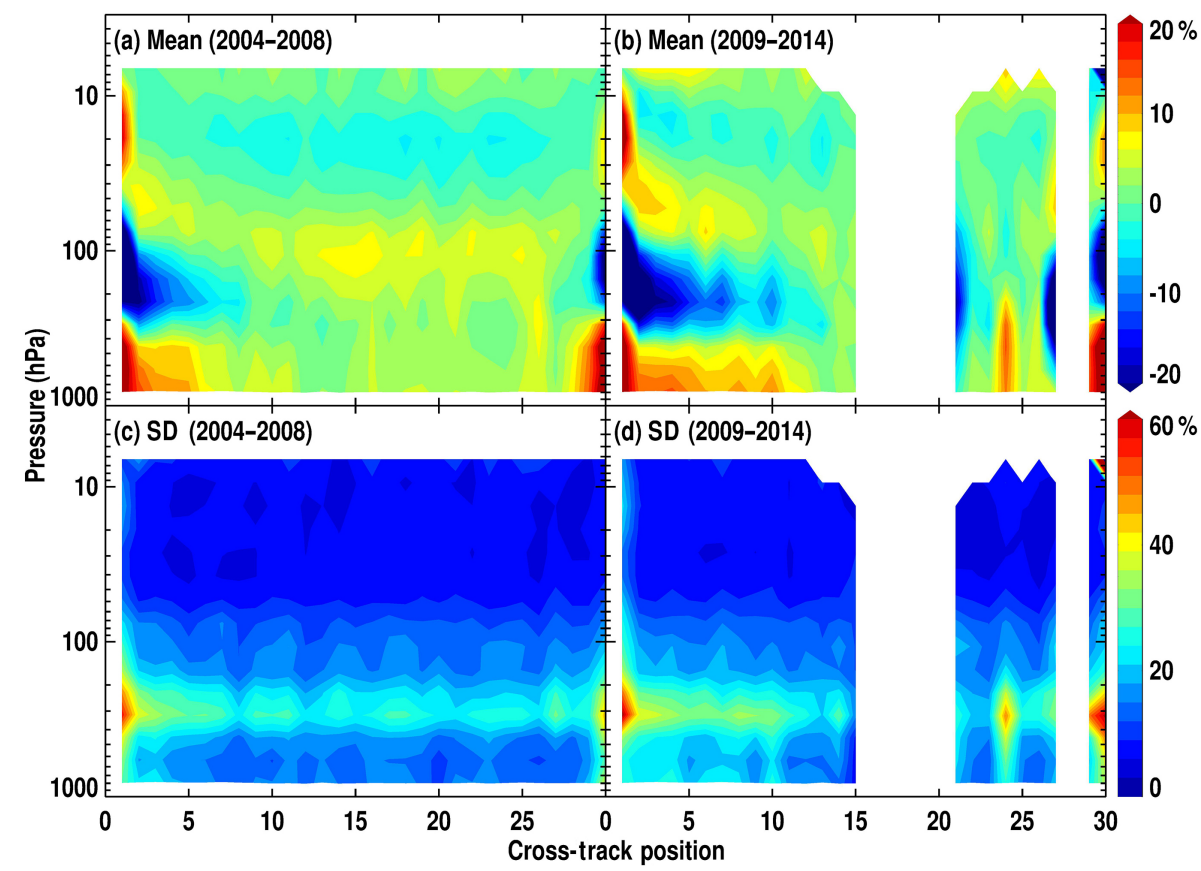

Figure 7. Same as Fig. 5 but as a function of cross-track position for (left) pre-RA (2004-2008) and (right) post-RA (2009-2014) periods.

function of cross-track position for pre-RA and post-RA periods, respectively. It clearly exhibits cross-track dependence especially with large positive/negative MBs and large SDs at the first/last several extreme off-nadir positions. This is why we select cross-track positions of 4-27 in the validation to avoid positions with large biases. The enhanced biases and SDs at positions 24 (RA flagging not applied) and 27 (flagged as RA in UV2 since 25 June 2007 but not flagged/applied in UV1) are due to the RA impact during the post-RA period. Cross-track positions 1-10 show consistent bias patterns with negative biases in $\sim 300-50 \mathrm{hPa}$ layer and positive biases in $\sim$ surface $300 \mathrm{hPa}$ layer and large standard deviation around $\sim 300 \mathrm{hPa}$, although the magnitude decreases with increasing cross-track position. This pattern occurs during both pre-RA and post-RA periods although the values are larger during the post-RA period. For other cross-track positions, the variation is relatively smaller but we can still see small striping patterns.

\subsection{Comparison of partial ozone columns}

We investigate and validate OMI partial ozone columns, including SOCs, TOCs, and surface- $550 \mathrm{hPa}$ and surface$750 \mathrm{hPa}$ ozone columns in this section. We define the lowermost one and two layers as surface- $750 \mathrm{hPa}$ and surface$550 \mathrm{hPa}$ in this paper, respectively, for convenience. Similarly, we also analyze the validation results of SOCs and TOCs during pre-RA and post-RA, respectively, to test the impacts of RA on OMI partial ozone columns. In addition, we validate ozone columns from the surface to $\sim 550 \mathrm{hPa}$ (bottom two layers) and $\sim 750 \mathrm{hPa}$ (bottom one layer) against ozonesonde observations in the tropics and midlatitude summer where there is better retrieval sensitivity to these quantities.

\subsubsection{Comparison of SOCs}

The left column of Fig. 8 shows the MBs and SDs of the comparisons of OMI and ozonesonde SOCs for each of the five latitude bands during 2004-2014. In all regions, the OMI SOCs have excellent agreement with ozonesonde SOCs regardless of whether ozonesonde data are convolved with OMI AKs. The application of OMI AKs to ozonesonde SOCs only slightly improves the comparison statistics. The MBs with OMI AKs are within $1.8 \%$ except for a negative bias of $3 \%$ at northern high latitudes, while the SDs are within $5.1 \%$ except for $5.7 \%$ at high latitudes. The correlation coefficient is greater than 0.95 except for 0.90 in the tropics due to the smaller SOC range. The SDs are typically larger than the comparisons with MLS data (Liu et al., 2010a) due to worse coincidence criteria, relatively larger uncertainty in the ozonesonde stratospheric ozone columns compared to MLS data, and different altitude ranges of integration.

The middle and right columns of Fig. 8 show comparison results during the pre-RA and post-RA periods, respectively. The comparison is typically better during the pre-RA with SDs smaller by $0.2-0.6 \%$ and larger correlation coefficients although the MBs are generally smaller during the post-RA period. One exception is at southern high latitudes where the post-RA comparison statistics are significantly better except 
(a) 2004-2014

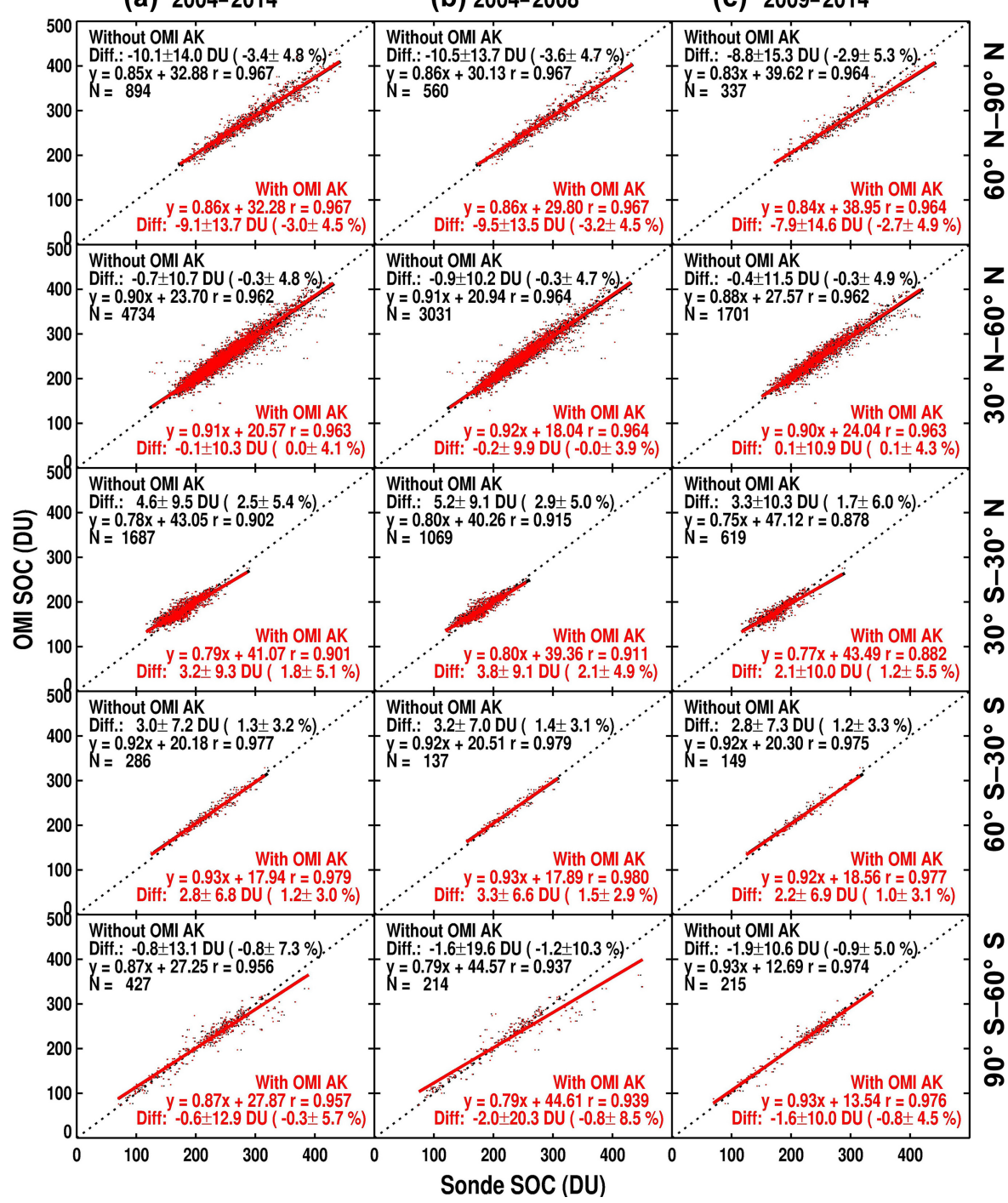

Figure 8. Scatter plots of OMI stratospheric ozone columns (SOCs) vs. ozonesonde SOCs without (black) and with (red) averaging kernels for five different latitude bands during 2004-2014 (a), the pre-row anomaly (RA) period (i.e., 2004-2008, b) and the post-RA period (i.e., 2009-2014, c), respectively. Comparison statistics including mean biases and standard deviations in both DU and \%, the linear regression and correlation coefficients in DU, and the number of coincidences are shown in the legends.

for the MB, consistent with Fig. 3, likely due to a combination of ozone variation between these two periods, uneven distribution of ozonesondes at different stations, and cancellation of various calibration errors.

\subsubsection{Comparison of partial ozone columns in the troposphere}

The left column of Fig. 9 shows the comparison of OMI and ozonesonde (with and without OMI AKs) TOCs for each of the five latitude bands during 2004-2014. Without applying OMI AKs, the MBs are within 1-3\% except for $9 \%$ at northern high latitudes; the SDs are within $20 \%$ in the tropics and midlatitudes and increase to $\sim 30-40 \%$ at high latitudes.
The correlation coefficient ranges from 0.83 in the tropics to $\sim 0.7$ at middle latitudes from 0.5 to 0.6 at high latitudes. The linear regression slopes are in the range 0.6-0.8, typically smaller at high latitudes due to reduced retrieval sensitivity to the lower troposphere. After applying the OMI AKs to ozonesonde data to remove smoothing errors, we see significant improvement in the comparison statistics except for MBs, which are within $6 \%$ at all latitudes. The SDs are reduced to within $15 \%$ in the tropics and middle latitudes and $\sim 30 \%$ (5.5-8.1 DU) at high latitudes; the correlation improves by $0.04-0.12$ and the slope significantly increases by $0.12-0.23$ to the range $0.8-1.0$ at different latitude bands due to accounting for inadequate retrieval sensitivity to the lower and middle troposphere. 
(a) 2004-2014

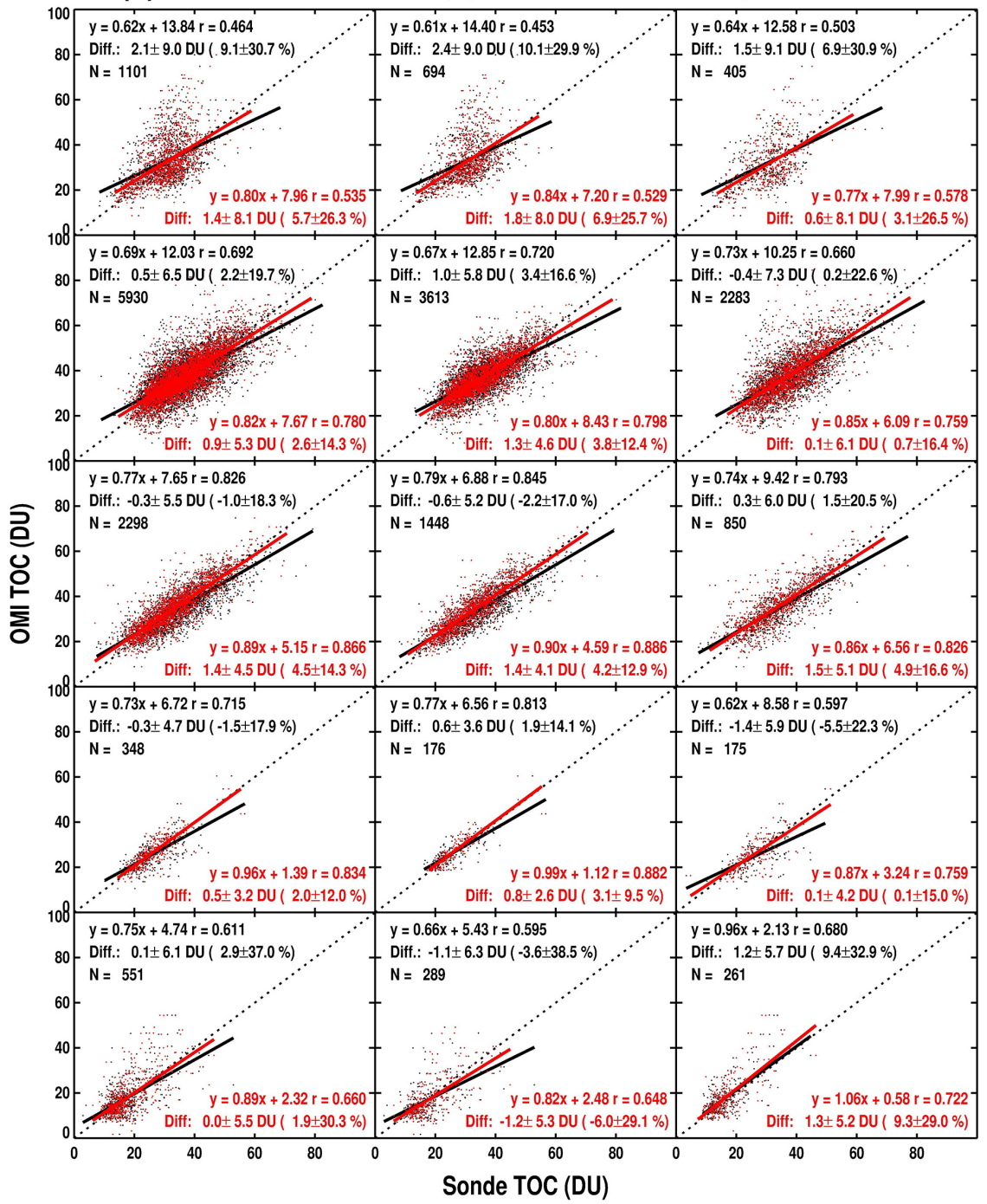

(c) $2009-2014$

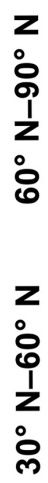

$z$
$\circ$
0
1
z
$\circ$
$\circ$

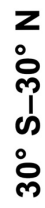

c

울

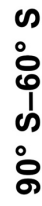

Figure 9. Similar to Fig. 8 but for comparison of tropospheric ozone columns (TOCs).

The middle and right columns of Fig. 9 show comparisons during pre-RA and post-RA, respectively. The comparison between OMI and ozonesondes with OMI AKs TOCs during the pre-RA period is significantly better than these during the post-RA period in the tropics and midlatitudes with SDs smaller by $3.4-5.5 \%$ and greater correlation. The MBs during the post-RA period is smaller by $\sim 2 \mathrm{DU}$ at midlatitudes but larger by $\sim 1 \mathrm{DU}$ in the tropics. However, the post-RA comparison is similar to the pre-RA comparison at northern high latitudes and is even better at southern high latitudes probably due to the aforementioned ozonesonde issues.

Figure 10 shows examples of time series when comparing individual OMI and ozonesondes (with OMI AKs) TOCs and their corresponding differences at six selected stations, one for each latitude region of $90-60^{\circ} \mathrm{N}, 60-30^{\circ} \mathrm{N}, 30^{\circ} \mathrm{N}-$ $0^{\circ}, 0-30^{\circ} \mathrm{S}, 30-60^{\circ} \mathrm{S}$, and $60-90^{\circ} \mathrm{S}$. OMI TOC shows good agreement with ozonesondes at these stations with overall $\mathrm{MBs} \leq 3 \mathrm{DU}$ and SDs less than 5.1 DU. The comparison is also good even in the high-latitude regions partially because the Summit and Neumayer stations only have OMIozonesonde comparison pairs during local summer. Seasonally dependent biases are clearly seen at Payerne, and bias trends can be seen at several stations with positive trends at Summit and Neumayer and a negative trend at Naha. In the pre-RA and post-RA periods, the MBs are typically within 2 DU and the SDs are typically smaller during the pre-RA period except for Naha. The better comparison (both MB and $\mathrm{SD})$ during the post-RA period at Naha is likely due to the switch to ECC ozonesondes beginning on 13 November 2008 from $\mathrm{KC}$ ozonesonde that have greater uncertainty (WMO, 1998). 


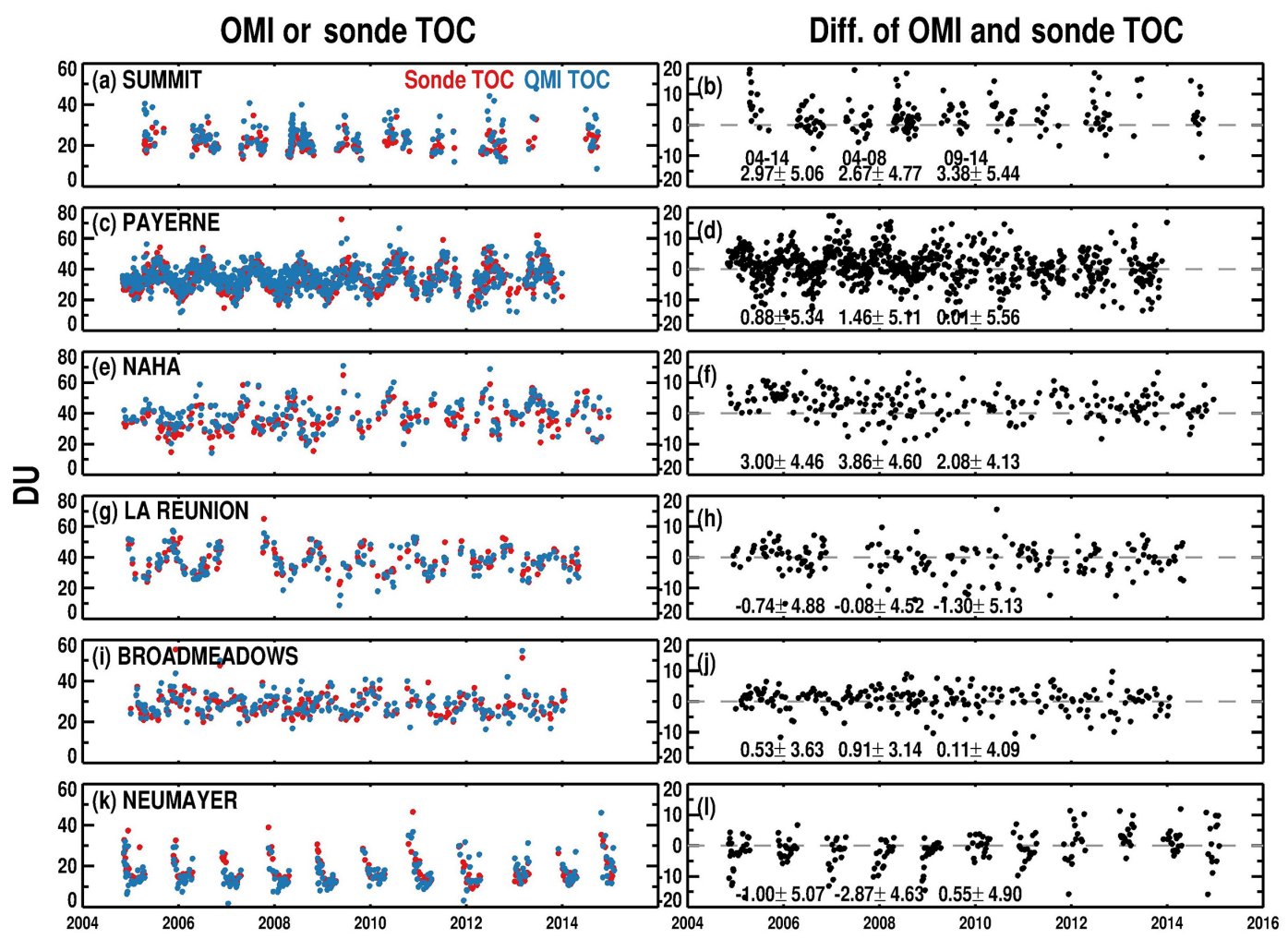

Figure 10. (a, c, e, g, i, k) Time series of OMI tropospheric ozone columns (TOCs) as green dots and ozonesonde TOCs (with OMI AKs applied) in Summit $\left(38.48^{\circ} \mathrm{W}, 72.57^{\circ} \mathrm{N}\right)$, Payene $\left(6.57^{\circ} \mathrm{E}, 46.49^{\circ} \mathrm{N}\right)$, Naha $\left(127.69^{\circ} \mathrm{E}, 26.21^{\circ} \mathrm{N}\right)$, La Réunion $\left(55.48^{\circ} \mathrm{E}, 21.06^{\circ} \mathrm{S}\right)$, Broadmeadows $\left(144.95^{\circ} \mathrm{E}, 58.74^{\circ} \mathrm{S}\right)$, and Neumayer $\left(8.27^{\circ} \mathrm{W}, 70.68^{\circ} \mathrm{S}\right)$, as well as $(\mathbf{b}, \mathbf{d}, \mathbf{f}, \mathbf{h}, \mathbf{j}, \mathbf{l})$ their corresponding differences, including the mean biases and standard deviations in 2004-2014, pre-RA (2004-2008) and post-RA (2009-2014) periods, respectively, in the legends.

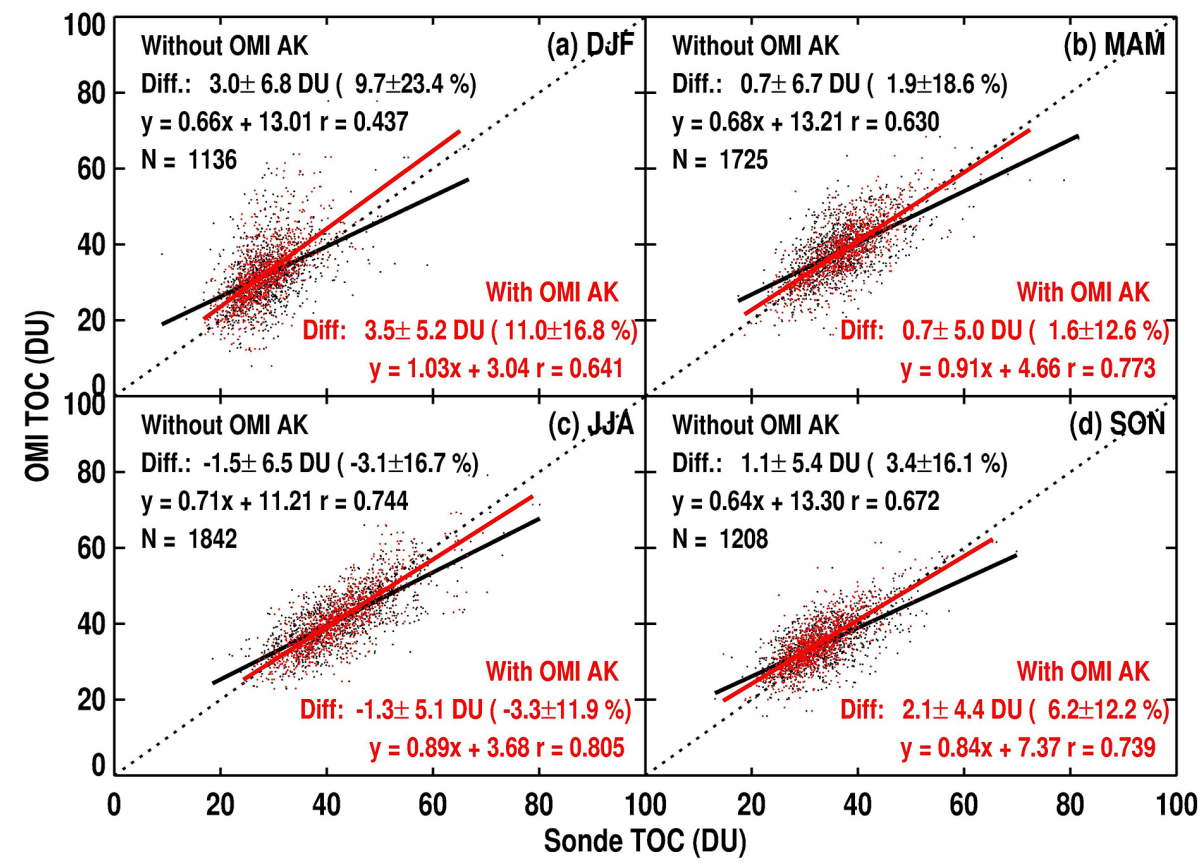

Figure 11. Similar to Fig. 9 but for different seasons at northern middle latitude during the 2004-2014 period. 
Figure 2 also shows the MBs and SDs of the TOC differences between OMI and ozonesonde convolved with OMI AKs at each station/location where there are at least 10 coincident OMI-ozonesonde pairs. OMI data generally exhibit good agreement with ozonesondes at most of the stations, with MBs of $\leq 3 \mathrm{DU}$ and SDs of $\leq 6 \mathrm{DU}$. In the tropics $\left(30^{\circ} \mathrm{S}-30^{\circ} \mathrm{N}\right)$, very large SDs (>11 DU) occur at the two Indian stations (New Delhi and Trivandrum). In addition, there is a large bias of $>6 \mathrm{DU}$ at New Delhi. The poor comparisons at these two stations are likely associated with the large uncertainties of the Indian ozonesonde data. Hilo has large biases of $\sim 4.5 \mathrm{DU}$ with 3.2 and $6.2 \mathrm{DU}$ for pre-RA and postRA, respectively. Java also has a large bias of $\sim 5 \mathrm{DU}$ but shows little difference between pre-RA and post-RA. Consistent $\sim 2$ and $\sim 5 \%$ underestimates of OC by ozonesondes compared to OMI total ozone are found in Hilo and Java, respectively (Thompson et al., 2012). These OC underestimates may partly explain the large TOC biases in Hilo and Java. However, the reason for underestimates of ozonesondederived OC is unknown. In the middle latitudes, noticeably large SDs and/or biases occur at a few stations such as Churchill, Sable Islands, Hohenpeissenberg, and Parah. Three Japanese stations, Sapporo, Tateno, and Naha, exhibit relatively large biases of 2-3 DU and even larger biases before switching from $\mathrm{KC}$ to ECC sondes. Almost half of the 11 northern high-latitude stations $\left(60-90^{\circ} \mathrm{N}\right)$ and two of the 6 southern high-latitude stations have large SDs/biases. In addition to retrieval biases from the OMI data, some of the large biases or SDs might be partially related to ozonesonde type with different biases and uncertainties due to different types (e.g., Indian sonde stations, BM ozonesonde at Hohenpeissenberg, three $\mathrm{KC}$ sonde stations), manufacturers (e.g., SP vs. ENSCI for ECC sonde), or sensor solution or related to individual sonde operations, which was shown in the validation of GOME ozone profile retrievals (Liu et al., 2006a).

Figure 11 shows the comparison for each season at northern midlatitudes. Consistent with profile comparison, the TOC comparison is dependent on season. When applying OMI AKs, the MB varies from $3 \mathrm{DU}$ in winter to $-1.5 \mathrm{DU}$ in summer. The SDs are within 6.8 DU with the smallest value during fall due to less ozone variability. The regression slopes are very close, within 0.04 around 0.67 . The retrieval sensitivity is smallest during the summer as seen from the greatest correlation and slope and relatively small standard deviation and is the worst during the winter. With OMI AKs applied to ozonesonde profiles, the MBs only slightly change (varying from 3.5 to $-1.3 \mathrm{DU}$ ), but the SDs are significantly reduced to within $5.2 \mathrm{DU}$, the slopes significantly increase by $\sim 0.2$ to $0.8-1.0$, and the correlation improves significantly during the winter and spring.

Figure 12 compares the surface- $550 \mathrm{hPa}$ and surface$750 \mathrm{hPa}$ ozone columns with ozonesonde data in the middle latitudes during summer and the tropics. Compared to the TOC comparisons in Figs. 9 and 11, the comparisons of these lower tropospheric ozone columns exhibit smaller re- gression slopes and correlations that are a result of reduced retrieval sensitivity. In the tropics, the slopes decrease from 0.78 in TOC to 0.65 in the surface- $550 \mathrm{hPa}$ ozone column and $\sim 0.50$ in the surface $-750 \mathrm{hPa}$ column, with corresponding correlation from 0.83 to 0.74 in the surface $-550 \mathrm{hPa}$ column, and 0.66 in the surface- $750 \mathrm{hPa}$ column. This indicates that the retrievals in the surface $-550 \mathrm{hPa} / 750 \mathrm{hPa}$ can capture $\sim 65 \% / 50 \%$ of the actual ozone change from the a priori. During the midlatitude summer, the slope decreases from 0.71 in the TOC comparisons to 0.42 in the surface$550 \mathrm{hPa}$ comparisons and 0.32 in the surface $-750 \mathrm{hPa}$ comparisons, with corresponding correlation coefficients from 0.74 to 0.5 and 0.46 . Thus, the retrievals in the surface$550 \mathrm{hPa}$ and $750 \mathrm{hPa}$ only capture $\sim 40 \% / 30 \%$ of the actual ozone change from the a priori. The MBs are generally small within $0.5 \mathrm{DU}(5 \%)$ with SDs of $\sim 3.6 \mathrm{DU}(20-28 \%)$ in the surface- $550 \mathrm{hPa}$ ozone column and $\sim 2.5 \mathrm{DU}(25-36 \%)$ in the surface- $750 \mathrm{hPa}$ ozone column. After applying OMI AKs to account for inadequate retrieval sensitivity and removing smoothing errors, the slope significantly increases to approach 1 (as expected). SDs are reduced to $\sim 10 \%$ in the middle latitudes and $\sim 15 \%$ in the tropics.

\subsection{Evaluation of long-term performance}

Comparisons in Sect. 4.1 and 4.2 indicated systematic differences between pre-RA and post-RA periods and generally worse performance during the post-RA periods. To further illustrate the long-term stability of our ozone profile product and understand the quality of OMI radiometric calibration as a function of time, we analyze monthly MBs of OMIozonesonde differences with OMI retrieval AKs in ozone profiles, SOCs, and TOCs. Due to the lack of OMI observations during some months at high latitudes, we focus on the evaluation by using coincidence pairs in $60^{\circ} \mathrm{S}-60^{\circ} \mathrm{N}$. Monthly MBs are calculated only if there are more than five OMI-ozonesonde pairs in a given month. Linear regression trend is on the MBs for the entire period (2004-2014) and/or for the pre-RA and post-RA periods, respectively. The trend is considered statistically significant if its $P$ value is less than 0.05 .

The linear trends of monthly mean ozone biases for each OMI layer between $60^{\circ} \mathrm{S}$ and $60^{\circ} \mathrm{N}$ are plotted in Fig. 13 for each of the three periods. During 2004-2014, marked in black, ozone biases at layers above $50.25 \mathrm{hPa}$ show significant positive trends of $0.06-0.17$ DU year $^{-1}(0.17-$ $0.52 \%$ year $^{-1}$ ), while ozone biases between 290 and $110 \mathrm{hPa}$ exhibit significant negative trends of 0.1-0.19 DU year ${ }^{-1}(1-$ $2 \%$ year $\left.^{-1}\right)$. The positive trends in the stratosphere are generally consistent with those shown in OMI-MLS comparisons (Huang et al., 2017). In the lowermost three OMI layers, ozone differences are more stable but with several large spikes during the post-RA periods likely due to the RA evolution or instrument operation. The derived trends for the preRA period are generally more flat and insignificant at all lay- 

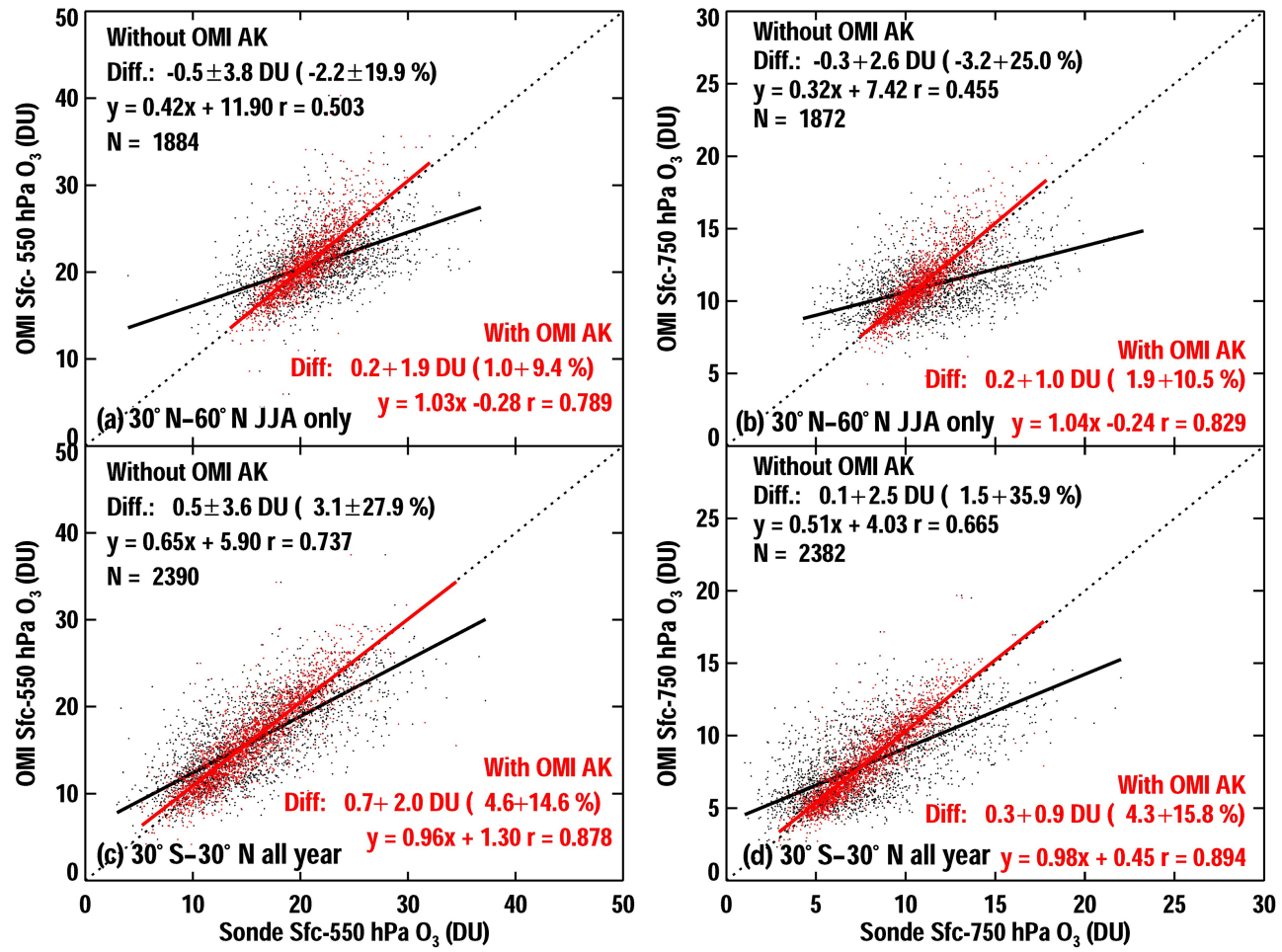

Figure 12. Similar to Fig. 9 but for comparison of lower tropospheric ozone columns during the 2004-2014 period. (a) Surface-550 hPa ozone column and (b) surface- $750 \mathrm{hPa}$ ozone column in $30-60^{\circ} \mathrm{N}$ during the summer; (c) and (d) same as (a) and (b) but for the tropics.

ers indicating good stability of our product as well as the OMI radiometric calibration. During the post-RA period, the derived trends are positive above $75 \mathrm{hPa}$ with statistical significance. These positive trends in the stratosphere are generally similar to those over the entire period, suggesting the dominant contribution of the post-RA period to the overall trend. In the altitude range $214-108 \mathrm{hPa}$, the post-RA trends are also flat similar to the pre-RA trends, but the values are systematically smaller during the post-RA period, causing significantly negative trends over the entire period.

The SOC biases exhibit small positive trend of $0.14 \pm 0.09$ DU year $^{-1}$ in 2004-2014 with no statistical significance (Fig. 14a). This slight positive trend is a result of trend cancellation by the positive trends above $80 \mathrm{hPa}$ and negative trends between 220 and $80 \mathrm{hPa}$. The TOC biases reveal a significant negative trend of $-0.18 \pm 0.05$ DU year $^{-1}$ (Fig. 14b), mostly from layers in the upper troposphere. In the pre-RA and post-RA periods, both trends of both SOC and TOC biases are relatively flat during the preRA period, while the SOC trend in the post-RA period is $0.77 \pm 0.20 \mathrm{DU}_{\text {year }}{ }^{-1}$ with significance. It is noticeable that the $P$ value of TOC trend in the post-RA period is 0.06 .

The significant trends of ozone biases at different layers as well as in SOC and TOC suggest that the current ozone profile product is not suitable for trend studies especially during the post-RA period. The relatively flat bias trends during the pre-RA periods and statistically significant trends during the post-RA period confirm that the better stability of our product during the pre-RA period and more temporal variation of the retrieval performance during the post-RA period are likely associated with the RA evolution. In previous sections, the validation of our retrievals revealed latitudinal/seasonal/SZA and cross-track-dependent biases even during the pre-RA period. This indicates the need to remove signal-dependent errors and the calibration inconsistency across the track. To maintain the spatial consistency and long-term stability of our ozone profile product, we need to further improve OMI's radiometric calibration especially during the post-RA period. Preferably, the calibration improvement should be done in the level $0-1 \mathrm{~b}$ processing. If this option is not possible, we can perform soft calibration similar to Liu et al. (2010b) but derive the correction as a function of time and latitude/SZA. In addition, it should be noted that the trend calculation might be affected by factors such as the availability of correction factors with ozonesondes (Morris et al., 2013), station-to-station variability, and the uneven spatiotemporal distribution of the ozonesondes, which can introduce considerable sampling biases (Liu et al., 2009; Saunois et al., 2012). 


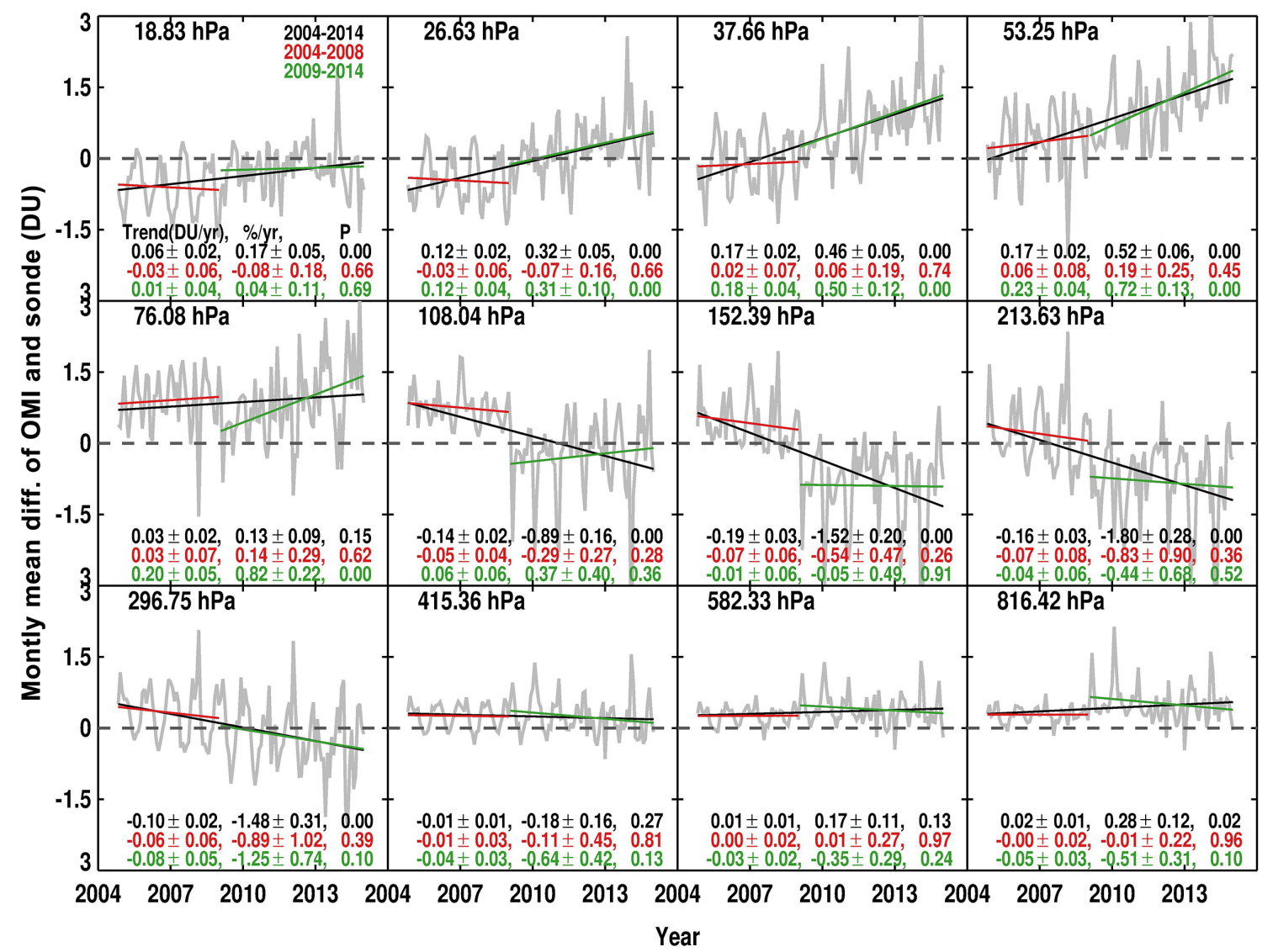

Figure 13. Monthly mean variation of OMI and ozonesonde mean biases in $60^{\circ} \mathrm{N}-60^{\circ} \mathrm{S}$ at each OMI layer. OMI retrieval averaging kernels are applied to ozonesonde data. The black, red, and green lines represent the linear ozone bias trends in 2004-2014, pre-RA (2004-2008), and post-RA (2009-2014), respectively. The average altitude of each layer is marked on the left corner of each grid. The trends in DU year ${ }^{-1}$ or $\%$ year and $P$ value for each time period are indicated in the legends.

\section{Summary and conclusion}

We conducted a comprehensive evaluation of the quality of OMI PROFOZ product produced by the SAO algorithm, including their spatial consistency and long-term performance using coincident global ozonesonde observations during the decade 2004-2014. To better understand retrieval errors and sensitivity, we compared the retrieved ozone profiles and a priori profile at individual layers with ozonesondes before and after being degraded to the OMI vertical resolution with OMI retrieval AKs. We also compared the integrated SOC, TOC, and surface- $550 / 750 \mathrm{hPa}$ ozone columns with ozonesonde data. To understand the spatial distribution of retrieval performance, the validations are grouped into five latitude ranges: northern and southern high and middle latitudes as well as the tropics. To investigate the impacts of the OMI RA on the retrievals, we contrasted the comparison before and after the occurrence of major OMI RA in January 2009, i.e., pre-RA (2004-2008) and post-RA (2009-2014) periods. In addition, we quantified the dependence of retrieval performance on seasonality and several key parameters includ- ing SZA, cloud fraction, and cross-track position. Finally, we analyzed the monthly mean variation of the MBs to examine the long-term stability of the PROFOZ product.

The comparison between OMI and ozonesonde profiles varies in altitude, with maximum SDs in the UTLS due to significant ozone variability, and varies with latitude similarly in the Northern and Southern hemispheres. There is good agreement throughout the atmosphere in the tropics and midlatitudes. With the application of OMI AKs to ozonesonde data, the MBs are within $6 \%$, and the SDs increase from $5-10 \%$ for pressure $<\sim 50 \mathrm{hPa}$ to within $18 \%$ $(27 \%)$ in the tropics/midlatitudes for pressure $>\sim 50 \mathrm{hPa}$. In the high latitudes, the retrievals agree well with ozonesondes only for pressure $<\sim 50 \mathrm{hPa}$ with MBs of $<10 \%$ and SDs of $5-15 \%$ for pressure $<\sim 50 \mathrm{hPa}$, but with MBs reaching $30 \%$ and SDs reaching $40 \%$ for pressure $>\sim 50 \mathrm{hPa}$. The comparison results are seasonally dependent. At northern midlatitudes, there are generally the best retrieval sensitivity and the smallest SDs as great as $20 \%$ in the summer, and the worst sensitivity and the largest SDs reaching $31 \%$ in the winter. The MBs near $300 \mathrm{hPa}$ vary from $12 \%$ in the 


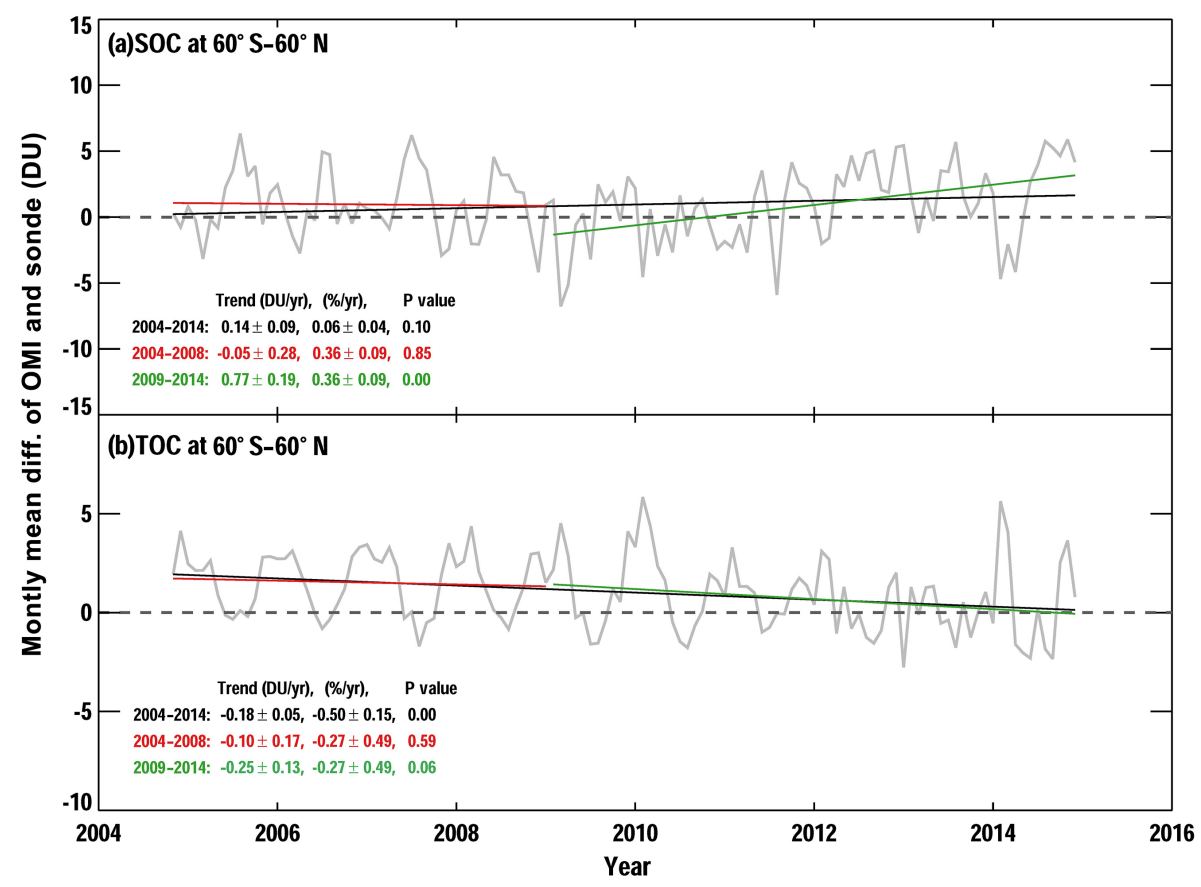

Figure 14. Same as Fig. 13 but for stratospheric ozone columns (SOCs) and tropospheric ozone columns (TOCs).

winter to $-10 \%$ in the summer. The post-RA comparison is generally worse in the tropics and midlatitudes than the pre-RA comparison, with SDs larger by up to $8 \%$ in the troposphere and $2 \%$ in the stratosphere and with larger MBs around $\sim 300 \mathrm{hPa}$ in the midlatitudes. But at high latitudes, the pre-RA comparison does not show persistent improvement over the post-RA comparison, with smaller biases and larger SDs at some altitudes, especially at southern high latitudes. The retrieval improvement over a priori can be determined from the SD reduction of the retrieval comparison from the a priori comparison. The retrievals demonstrate clear improvement over the a priori down to the surface in the tropics, but only down to $\sim 750 \mathrm{hPa}$ during midlatitude summer, $\sim 550 \mathrm{hPa}$ during the other seasons of midlatitudes, and $\sim 300 \mathrm{hPa}$ at high latitudes.

Retrieval performance typically becomes worse at large SZA, especially at SZA larger than $75^{\circ}$, where the MBs in the troposphere are $>20 \%$ and the SDs near $\sim 300 \mathrm{hPa}$ are $>45 \%$. The worse performance at larger SZA is due to a combination of weaker signal and greater influence by radiometric calibration errors such as due to stray light and radiative transfer calculation errors. The variation of SZA is likely responsible for the majority of the retrieval dependence on latitude and season. The retrieval quality for pressure $>\sim 100 \mathrm{hPa}$ degrades with increasing cloudiness in terms of MBs and SDs, with MBs greater than $10 \%$ at cloud fraction $>0.3$. The retrieval performance also varies with cross-track position, especially with large MBs and SDs at the first/last extreme off-nadir positions (e.g., 1-3 and 28-30). The dependence is stronger during the post-RA period.
The integrated SOCs and TOCs also exhibit good agreement with ozonesondes. With the convolution of OMI AKs to ozonesonde data, the SOC MBs are within $2 \%$ with SDs within $\sim 5.1 \%$ in the tropics and midlatitudes. These statistics do not change much even without the applications of OMI AKs. The comparison becomes slightly worse at high latitudes, with MBs up to $3 \%$ and SDs up to $6 \%$. The pre-RA comparison is generally better with smaller SDs of $0.2-0.6 \%$ except for southern high latitudes, although with slightly larger MBs. The TOC MBs and SDs with OMI AKs are within $6 \%$, with SDs of $<\sim 15 \%$ in the tropics and midlatitudes but reach $30 \%$ at high latitudes. The pre-RA TOC comparison is also better in the tropics and midlatitudes with SDs smaller by $3.4-5.5 \%$ but worse values at southern high latitudes. The TOC comparison at northern midlatitudes varies with season, with MBs of $11 \%$. There are worse correlation during winter and MBs of $-3 \%$ and best correlation in summer. The TOC comparison also shows noticeable stationto-station variability in similar latitude ranges with much larger MBs and/or SDs at the two Indian stations and larger MBs at several Japanese stations before they switched from KC ozonesondes to ECC ozonesondes. This demonstrates the impacts of ozonesonde uncertainties due to sonde types, manufacturers, sensor solution, and operations. Without applying OMI AKs, the TOC correlation with ozonesondes typically becomes worse at higher latitudes, ranging from 0.83 in the tropics to $0.5-0.6$ at high latitudes. The linear regression slope is within 0.6-0.8, typically smaller at higher latitudes, reflecting the smaller retrieval sensitivity down to the troposphere at higher latitudes mainly resulting from larger 
SZA. The convolution of AKs significantly improves the correlation and slope. The impact of retrieval sensitivity related to SZA is also reflected in the seasonal dependence of the comparison at midlatitudes.

The surface-550/750 hPa ozone columns in the tropics during midlatitude summer compare quite well with ozonesonde data, with MBs of $<5 \%$ and SDs of 20 $25 \% / 28-36 \%$ without OMI AKs. The correlation and slope decrease with decreasing altitude range due to reduced retrieval sensitivity down to the lower troposphere. These columns capture $\sim 65 \% / 50 \%$ of the actual ozone change in the tropics and $\sim 40 \% / 30 \%$ in the troposphere. Convolving ozonesonde data with OMI AKs significantly increases the slope to $\sim 1$ and reduces the SDs to $10-15 \%$.

The contrast of pre-RA and post-RA comparisons indicates generally worse post-RA performance with larger SDs. Linear trend analysis of the OMI-ozonesonde monthly MBs further reveals additional RA impact. The temporal performance over $60^{\circ} \mathrm{S}-60^{\circ} \mathrm{N}$ is generally stable with no statistically significant trend during the pre-RA period, but it displays a statistically significant trend of $0.14-0.7 \%$ year $^{-1}$ at individual layers for pressure $<\sim 80 \mathrm{hPa}, 0.7 \mathrm{DU}_{\text {year }}{ }^{-1}$ in SOC, and -0.33 DU year $^{-1}$ in TOC during the post-RA period. Because of these artificial trends in our product, we caution against using our product for ozone trend studies.

This validation study demonstrates generally good retrieval performance of our ozone profile product especially in the tropics and midlatitudes during the pre-RA period. However, the spatiotemporal variation of retrieval performance suggests that OMI's radiometric calibration should be improved, especially during the post-RA period, including the removal of signal-dependent errors, calibration inconsistency across the track and with time to maintain the long-term stability, and spatial consistency of our ozone profile product.

Data availability. OMI PROFOZ (version 0.9.3) used in this study is available to users at Aura Validation Data Center (AVDC) (https: //avdc.gsfc.nasa.gov/index.php?site=1389025893\&id=74).

Competing interests. The authors declare that they have no conflict of interest.

Acknowledgements. This study was supported by the NASA Atmospheric Composition: Aura Science Team (NNX14AF16G) and the Smithsonian Institution. The Dutch-Finnish OMI instrument is part of the NASA EOS Aura satellite payload. The OMI Project is managed by NIVR and KNMI in the Netherlands. We acknowledge the OMI International Science Team for producing OMI data. We also acknowledge the ozonesonde providers and their funding agencies for making ozonesonde measurements, and the Aura Validation Data Center (AVDC), WOUDC, SHADOZ, DISCOVER-AQ, and SEACR ${ }^{4} \mathrm{~S}$ for archiving the ozonesonde data.
Edited by: Piet Stammes

Reviewed by: two anonymous referees

\section{References}

Antón, M. and Loyola, D.: Influence of cloud properties on satellite total ozone observations, J. Geophys. Res., 116, D03208, https://doi.org/10.1029/2010JD014780, 2011.

Bak, J., Kim, J. H., Liu, X., Chance, K., and Kim, J.: Evaluation of ozone profile and tropospheric ozone retrievals from GEMS and OMI spectra, Atmos. Meas. Tech., 6, 239-249, https://doi.org/10.5194/amt-6-239-2013, 2013a.

Bak, J., Liu, X., Wei, J. C., Pan, L. L., Chance, K., and Kim, J. H.: Improvement of OMI ozone profile retrievals in the upper troposphere and lower stratosphere by the use of a tropopausebased ozone profile climatology, Atmos. Meas. Tech., 6, 22392254, https://doi.org/10.5194/amt-6-2239-2013, 2013 b.

Bak, J., Liu, X., Kim, J. H., Chance, K., and Haffner, D. P.: Validation of OMI total ozone retrievals from the SAO ozone profile algorithm and three operational algorithms with Brewer measurements, Atmos. Chem. Phys., 15, 667-683, https://doi.org/10.5194/acp-15-667-2015, 2015.

Bhartia, P. K. and Wellemeyer, C. G.: TOMS-V8 total ozone algorithm, in: OMI Algorithm Theoretical Basis Document, edited by: Bhartia, P. K., Greenbelt, 2002.

Cai, Z., Liu, Y., Liu, X., Chance, K., Nowlan, C. R., Lang, R., Munro, R., and Suleiman, R.: Characterization and correction of Global Ozone Monitoring Experiment 2 ultraviolet measurements and application to ozone profile retrievals, J. Geophys. Res., 117, D07305, https://doi.org/10.1029/2011jd017096, 2012.

Caudill, T. R., Flittner, D. E., Herman, B. M., Torres, O., and McPeters, R. D.: Evaluation of the pseudo-spherical approximation for backscattered ultraviolet radiances and ozone retrieval, J. Geophys. Res., 102, 3881-3890, 1997.

Claas, J.: OMI and AURA: Status, Instrument, Spacecraft and Operations, OMI Science Meeting Meeting, De Bilt, the Netherlands, 2014.

Deshler, T., Mercer, J. L., Smit, H. G. J., Stubi, R., Levrat, G., Johnson, B. J., Oltmans, S. J., Kivi, R., Thompson, A. M., Witte, J., Davies, J., Schmidlin, F. J., Brothers, G., and Sasaki, T.: Atmospheric comparison of electrochemical cell ozonesondes from different manufacturers, and with different cathode solution strengths: The Balloon Experiment on Standards for Ozonesondes, J. Geophys. Res., 113, D04307, https://doi.org/10.1029/2007JD008975, 2008.

Hassler, B., Petropavlovskikh, I., Staehelin, J., August, T., Bhartia, P. K., Clerbaux, C., Degenstein, D., Mazière, M. D., Dinelli, B M., Dudhia, A., Dufour, G., Frith, S. M., Froidevaux, L., GodinBeekmann, S., Granville, J., Harris, N. R. P., Hoppel, K., Hubert, D., Kasai, Y., Kurylo, M. J., Kyrölä, E., Lambert, J.-C., Levelt, P. F., McElroy, C. T., McPeters, R. D., Munro, R., Nakajima, H., Parrish, A., Raspollini, P., Remsberg, E. E., Rosenlof, K. H., Rozanov, A., Sano, T., Sasano, Y., Shiotani, M., Smit, H. G. J., Stiller, G., Tamminen, J., Tarasick, D. W., Urban, J., van der A, R. J., Veefkind, J. P., Vigouroux, C., von Clarmann, T., von Savigny, C., Walker, K. A., Weber, M., Wild, J., and Zawodny, J. M.: Past changes in the vertical distribution of ozone - Part 1: Measurement techniques, uncertainties and availability, Atmos. 
Meas. Tech., 7, 1395-1427, https://doi.org/10.5194/amt-7-13952014, 2014.

Hayashida, S., Liu, X., Ono, A., Yang, K., and Chance, K.: Observation of ozone enhancement in the lower troposphere over East Asia from a space-borne ultraviolet spectrometer, Atmos. Chem. Phys., 15, 9865-9881, https://doi.org/10.5194/acp-159865-2015, 2015.

Huang, G., Newchurch, M. J., Kuang, S., Buckley, P. I., Cantrell, W., and Wang, L.: Definition and determination of ozone laminae using Continuous Wavelet Transform (CWT) analysis, Atmos. Environ., 104, 125-131, https://doi.org/10.1016/j.atmosenv.2014.12.027, 2015.

Huang, G., Liu, X., Chance, K., Yang, K., and Cai, Z.: Validation of 10-year SAO OMI Ozone Profile (PROFOZ) Product Using Aura MLS Measurements, Atmos. Meas. Tech. Discuss., https://doi.org/10.5194/amt-2017-92, in review, 2017.

Johnson, B. J.: Electrochemical concentration cell (ECC) ozonesonde pump efficiency measurements and tests on the sensitivity to ozone of buffered and unbuffered ECC sensor cathode solutions, IEEE T. Geosci. Remote., 107, 4393, https://doi.org/10.1029/2001jd000557, 2002.

Kim, P. S., Jacob, D. J., Liu, X., Warner, J. X., Yang, K., Chance, K., Thouret, V., and Nedelec, P.: Global ozone-CO correlations from OMI and AIRS: constraints on tropospheric ozone sources, Atmos. Chem. Phys., 13, 9321-9335, https://doi.org/10.5194/acp13-9321-2013, 2013

Kivi, R., Kyrö, E., Turunen, T., Harris, N. R. P., von der Gathen, P., Rex, M., Andersen, S. B., and Wohltmann, I.: Ozonesonde observations in the Arctic during 19892003: Ozone variability and trends in the lower stratosphere and free troposphere, J. Geophys. Res., 112, D08306, https://doi.org/10.1029/2006JD007271, 2007.

Komhyr, W. D.: Operations on handbook-Ozone measurements to 40-km altitude with model 4A electrochemical concentration cell (ECC) ozonesondes, NOAA Tech. Memo., ERLARL-149 Air Resour. Lab., Boulder, CO, 49 pp., 1986.

Komhyr, W. D., Connor, B. J., McDermid, I. S., McGee, T. J., Parrish, A. D., and Margitan, J. J.: Comparison of STOIC 1989 ground-based lidar, microwave spectrometer, and Dobson spectrophotometer Umkehr ozone profiles with ozone profiles from balloon-borne electrochemical concentration cell ozonesondes, J. Geophys. Res., 100, 9273-9282, 1995.

Kroon, M., de Haan, J. F., Veefkind, J. P., Froidevaux, L., Wang, R., Kivi, R., and Hakkarainen, J. J.: Validation of operational ozone profiles from the Ozone Monitoring Instrument, J. Geophys. Res., 116, D18305, https://doi.org/10.1029/2010jd015100, 2011.

Lal, S., Venkataramani, S., Srivastava, S., Gupta, S., Mallik, C., Naja, M., Sarangi, T., Acharya, Y. B., and Liu, X.: Transport effects on the vertical distribution of tropospheric ozone over the tropical marine regions surrounding India, J. Geophys. Res., 118, 1513-1524, 2013.

Levelt, P. F., van den Oord, G. H. J., Dobber, M. R., Malkki, A., Visser, H., de Vries, J., Stammes, P., Lundell, J. O. V., and Saari, H.: The Ozone Monitoring Instrument, IEEE T. Geosci. Remote., 44, 1093-1101, 2006.

Liu, G., Liu, J., Tarasick, D. W., Fioletov, V. E., Jin, J. J., Moeini, O., Liu, X., Sioris, C. E., and Osman, M.: A global tropospheric ozone climatology from trajectory-mapped ozone soundings, Atmos. Chem. Phys., 13, 10659-10675, https://doi.org/10.5194/acp-13-10659-2013, 2013.

Liu, G., Tarasick, D. W., Fioletov, V. E., Sioris, C. E., and Rochon, Y. J.: Ozone correlation lengths and measurement uncertainties from analysis of historical ozonesonde data in North America and Europe, J. Geophys. Res., 114, D04112, https://doi.org/10.1029/2008JD010576, 2009.

Liu, X., Chance, K., Sioris, C. E., Spurr, R. J. D., Kurosu, T. P., Martin, R. V., and Newchurch, M. J.: Ozone profile and tropospheric ozone retrievals from the Global Ozone Monitoring Experiment: Algorithm description and validation, J. Geophys. Res., 110, D20307, https://doi.org/10.1029/2005jd006240, 2005.

Liu, X., Chance, K., Sioris, C. E., Kurosu, T. P., and Newchurch, M. J.: Intercomparison of GOME, ozonesonde, and SAGE II measurements of ozone: Demonstration of the need to homogenize available ozonesonde data sets, J. Geophys. Res., 111, D114305, https://doi.org/10.1029/2005jd006718, 2006a.

Liu, X., Chance, K., Sioris, C. E., Kurosu, T. P., Spurr, R. J. D., Martin, R. V., Fu, T.-M., Logan, J. A., Jacob, D. J., Palmer, P. I., Newchurch, M. J., Megretskaia, I. A., and Chatfield, R. B.: First directly retrieved global distribution of tropospheric column ozone from GOME: Comparison with the GEOS-CHEM model, J. Geophys. Res., 111, D02308, https://doi.org/10.1029/2005JD006564, 2006b.

Liu, X., Chance, K., and Kurosu, T. P.: Improved ozone profile retrievals from GOME data with degradation correction in reflectance, Atmos. Chem. Phys., 7, 1575-1583, https://doi.org/10.5194/acp-7-1575-2007, 2007.

Liu, X., Bhartia, P. K., Chance, K., Froidevaux, L., Spurr, R. J. D., and Kurosu, T. P.: Validation of Ozone Monitoring Instrument (OMI) ozone profiles and stratospheric ozone columns with Microwave Limb Sounder (MLS) measurements, Atmos. Chem. Phys., 10, 2539-2549, https://doi.org/10.5194/acp-102539-2010, 2010a.

Liu, X., Bhartia, P. K., Chance, K., Spurr, R. J. D., and Kurosu, T. P.: Ozone profile retrievals from the Ozone Monitoring Instrument, Atmos. Chem. Phys., 10, 2521-2537, https://doi.org/10.5194/acp-10-2521-2010, 2010b.

McPeters, R. D., Labow, G. J., and Logan, J. A.: Ozone climatological profiles for satellite retrieval algorithms, J. Geophys. Res., 112, D05308, https://doi.org/10.1029/2005jd006823, 2007.

Morris, G. A., Labow, G., Akimoto, H., Takigawa, M., Fujiwara, M., Hasebe, F., Hirokawa, J., and Koide, T.: On the use of the correction factor with Japanese ozonesonde data, Atmos. Chem. Phys., 13, 1243-1260, https://doi.org/10.5194/acp-131243-2013, 2013.

Pittman, J. V., Pan, L. L., Wei, J. C., Irion, F. W., Liu, X., Maddy, E. S., Barnet, C. D., Chance, K., and Gao, R.-S.: Evaluation of AIRS, IASI, and OMI ozone profile retrievals in the extratropical tropopause region using in situ aircraft measurements, J. Geophys. Res., 114, 24109, https://doi.org/10.1029/2009jd012493, 2009.

Saunois, M., Emmons, L., Lamarque, J.-F., Tilmes, S., Wespes, C., Thouret, V., and Schultz, M.: Impact of sampling frequency in the analysis of tropospheric ozone observations, Atmos. Chem. Phys., 12, 6757-6773, https://doi.org/10.5194/acp12-6757-2012, 2012.

Sellitto, P., Bojkov, B. R., Liu, X., Chance, K., and Del Frate, F.: Tropospheric ozone column retrieval at northern mid-latitudes 
from the Ozone Monitoring Instrument by means of a neural network algorithm, Atmos. Meas. Tech., 4, 2375-2388, https://doi.org/10.5194/amt-4-2375-2011, 2011.

Smit, H. G. J., Straeter, W., Johnson, B. J., Oltmans, S. J., Davies, J., Tarasick, D. W., Hoegger, B., Stubi, R., Schmidlin, F. J., Northam, T., Thompson, A. M., Witte, J. C., Boyd, I., and Posny, F.: Assessment of the performance of ECC-ozonesondes under quasi-flight conditions in the environmental simulation chamber: Insights from the Juelich Ozone Sonde Intercomparison Experiment (JOSIE), J. Geophys. Res., 112, D19306, https://doi.org/10.1029/2006JD007308, 2007.

Tarasick, D. W., Jin, J. J., Fioletov, V. E., Liu, G., Thompson, A. M., Oltmans, S. J., Liu, J., Sioris, C. E., Liu, X., Cooper, O. R., Dann, T., and Thouret, V.: Highresolution tropospheric ozone fields for INTEX and ARCTAS from IONS ozonesondes, J. Geophys. Res., 115, D20301, https://doi.org/10.1029/2009JD012918, 2010.

Thompson, A. M., Yorks, J. E., Miller, S. K., Witte, J. C., Dougherty, K. M., Morris, G. A., Baumgardner, D., Ladino, L., and Rappenglück, B.: Tropospheric ozone sources and wave activity over Mexico City and Houston during MILAGRO/Intercontinental Transport Experiment (INTEX-B) Ozonesonde Network Study, 2006 (IONS-06), Atmos. Chem. Phys., 8, 5113-5125, https://doi.org/10.5194/acp-8-5113-2008, 2008.

Thompson, A. M., Stone, J. B., Witte, J. C., Miller, S. K., Oltmans, S. J., Kucsera, T. L., Ross, K. L., Pickering, K. E., Merrill, J. T., Forbes, G., Tarasick, D. W., Joseph, E., Schmidlin, F. J., McMillan, W. W., Warner, J., Hintsa, E. J., and Johnson, J. E.: Intercontinental Chemical Transport Experiment Ozonesonde Network Study (IONS) 2004: 2. Tropospheric ozone budgets and variability over northeastern North America, J. Geophys. Res., 112, D12S13, https://doi.org/10.1029/2006jd007670, 2007a.

Thompson, A. M., Stone, J. B., Witte, J. C., Miller, S. K., Pierce, R. B., Chatfield, R. B., Oltmans, S. J., Cooper, O. R., Loucks, A. L., Taubman, B. F., Johnson, B. J., Joseph, E., Kucsera, T. L., Merrill, J. T., Morris, G. A., Hersey, S., Forbes, G., Newchurch, M. J., Schmidlin, F. J., Tarasick, D. W., Thouret, V., and Cammas, J.-P.: Intercontinental Chemical Transport Experiment Ozonesonde Network Study (IONS) 2004: 1. Summertime upper troposphere/lower stratosphere ozone over northeastern North America, J. Geophys. Res., 112, D12S12, https://doi.org/10.1029/2006jd007441, 2007b.

Thompson, A. M., Witte, J. C., Smit, H. G. J., Oltmans, S. J., Johnson, B. J., Kirchhoff, V. W. J. H., and Schmidlin, F. J.: Southern Hemisphere Additional Ozonesondes (SHADOZ) 1998-2004 tropical ozone climatology: 3. Instrumentation, station-to-station variability, and evaluation with simulated flight profiles, J. Geophys. Res., 112, D03304, https://doi.org/10.1029/2005jd007042, 2007c.

Thompson, A. M., Miller, S. K., Tilmes, S., Kollonige, D. W., Witte, J. C., Oltmans, S. J., Johnson, B. J., Fujiwara, M., Schmidlin, F. J., Coetzee, G. J. R., Komala, N., Maata, M., bt Mohamad, M., Nguyo, J., Mutai, C., Ogino, S. Y., Da Silva, F. R., Leme, N. M. P., Posny, F., Scheele, R., Selkirk, H. B., Shiotani, M., Stübi, R., Levrat, G., Calpini, B., Thouret, V., Tsuruta, H., Canossa, J. V., Vömel, H., Yonemura, S., Diaz, J. A., Tan Thanh, N. T., and Thuy Ha, H. T.: Southern Hemisphere Additional Ozonesondes (SHADOZ) ozone climatology (2005-2009): Tropospheric and tropical tropopause layer (TTL) profiles with comparisons to OMI-based ozone products, J. Geophys. Res., 117, D23301, https://doi.org/10.1029/2011jd016911, 2012.

Thompson, A. M., Stauffer, R. M., Miller, S. K., Martins, D. K., Joseph, E., Weinheimer, A. J., and Diskin, G. S.: Ozone profiles in the Baltimore-Washington region (2006-2011): satellite comparisons and DISCOVER-AQ observations, J. Atmos. Chem., 72, 393-422, https://doi.org/10.1007/s10874-014-9283-z, 2015.

Toon, O. B., Maring, H., Dibb, J., Ferrare, R., Jacob, D. J., Jensen, E. J., Luo, Z. J., Mace, G. G., Pan, L. L., Pfister, L., Rosenlof, K. H., Redemann, J., Reid, J. S., Singh, H. B., Thompson, A. M., Yokelson, R., Minnis, P., Chen, G., Jucks, K. W., and Pszenny, A.: Planning, implementation, and scientific goals of the Studies of Emissions and Atmospheric Composition, Clouds and Climate Coupling by Regional Surveys (SEAC4RS) field mission, J. Geophys. Res., 121, 4967-5009, https://doi.org/10.1002/2015jd024297, 2016.

van Oss, R. F., Voors, R. H. M., and Spurr, R. J. D.: Ozone profile algorithm, in: OMI Algorithm Theoretical Basis Document, Volume II: OMI ozone products, edited by: Bhartia, P. K., Greenbelt, MD, 51-73, 2001.

Vasilkov, A., Joiner, J., Spurr, R., Bhartia, P. K., Levelt, P., and Stephens, G.: Evaluation of the OMI cloud pressures derived from rotational Raman scattering by comparisons with other satellite data and radiative transfer simulations, J. Geophys. Res.Atmos., 113, D15S19, https://doi.org/10.1029/2007JD008689, 2008.

Veefkind, J. P., de Haan, J. F., Brinksma, E. J., Kroon, M., and Levelt, P. F.: Total Ozone From the Ozone Monitoring Instrument (OMI) Using the DOAS Technique, IEEE T. Geosci. Remote., 44, 1239-1244, 2006.

Wang, L., Newchurch, M. J., Biazar, A., Liu, X., Kuang, S., Khan, M., and Chance, K.: Evaluating AURA/OMI ozone profiles using ozonesonde data and EPA surface measurements for August 2006, Atmos. Environ., 45, 5523-5530, https://doi.org/10.1016/j.atmosenv.2011.06.012, 2011.

WMO: SPARC/IO3C/GAW Assessment of trends in the vertical distribution of ozone, GenevaRep. 43, 1998.

Worden, H. M., Logan, J. A., Worden, J. R., Beer, R., Bowman, K., Clough, S. A., Eldering, A., Fisher, B. M., Gunson, M. R., Herman, R. L., Kulawik, S. S., Lampel, M. C., Luo, M., Megretskaia, I. A., Osterman, G. B., and Shephard, M. W.: Comparisons of Tropospheric Emission Spectrometer (TES) ozone profiles to ozonesondes: Methods and initial results, J. Geophys. Res., 112, D03309, https://doi.org/10.1029/2006jd007258, 2007.

Yang, Q., Cunnold, D. M., Wang, H. J., Froidevaux, L., Claude, H., Merrill, J., Newchurch, M., and Oltmans, S. J.: Midlatitude tropospheric ozone columns derived from the Aura Ozone Monitoring Instrument and Microwave Limb Sounder measurements, J. Geophys. Res.-Atmos., 112, D20305, https://doi.org/10.1029/2007JD008528, 2007.

Ziemke, J. R., Olsen, M. A., Witte, J. C., Douglass, A. R., Strahan, S. E., Wargan, K., Liu, X., Schoeberl, M. R., Yang, K., Kaplan, T. B., Pawson, S., Duncan, B. N., Newman, P. A., Bhartia, P. K., and Heney, M. K.: Assessment and applications of NASA ozone data products derived from Aura OMI/MLS satellite measurements in context of the GMI chemical transport model, J. Geophys. Res., 119, 5671-5699, https://doi.org/10.1002/2013jd020914, 2014. 